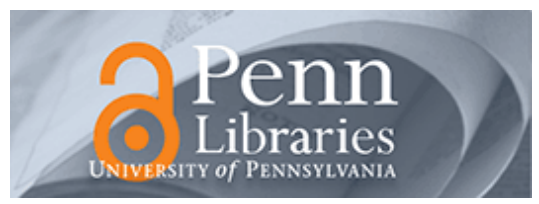

University of Pennsylvania ScholarlyCommons

February 2006

\title{
Patterns in cumulative increase in live and dead species from foraminiferal time series of Cowpen Marsh, Tees Estuary, UK: Implications for sea-level studies
}

\author{
Benjamin P. Horton \\ University of Pennsylvania, bphorton@sas.upenn.edu \\ John W. Murray \\ National Oceanography Centre
}

Follow this and additional works at: https://repository.upenn.edu/ees_papers

\section{Recommended Citation}

Horton, B. P., \& Murray, J. W. (2006). Patterns in cumulative increase in live and dead species from foraminiferal time series of Cowpen Marsh, Tees Estuary, UK: Implications for sea-level studies . Retrieved from https://repository.upenn.edu/ees_papers/37

Postprint version. Published in Marine Micropaleontology, Volume 58, Issue 4, 2006, pages 287-315.

Publisher URL: http://dx.doi.org/10.1016/j.marmicro.2005.10.006

This paper is posted at ScholarlyCommons. https://repository.upenn.edu/ees_papers/37

For more information, please contact repository@pobox.upenn.edu. 


\title{
Patterns in cumulative increase in live and dead species from foraminiferal time series of Cowpen Marsh, Tees Estuary, UK: Implications for sea-level studies
}

\begin{abstract}
We have collected live and dead foraminiferal times-series data at 2-weekly intervals for a 12-month period from the intertidal zone of Cowpen Marsh, Tees Estuary, UK. The data from the 689 samples show profound differences between live and dead assemblages, although assemblages are dominated by just three species, Haynesina germanica, Jadammina macrescens and Trochammina inflata, which represent over $70 \%$ of the assemblage. The cumulative increase in species of most environments approximates to a lognormal or log series. None of the datasets show a broken stick pattern. The cumulative maximum number of species, which represents the species carrying capacity of the environment, is recorded earlier in the life assemblages than the dead counterparts. The dead assemblage of Cowpen Marsh is found to have a higher abundance ( 435 compared to 163 individuals $/ 10 \mathrm{~cm}^{3}$ ) and number of species (52 compared to 28) than its live counterpart because the dead assemblage represents many generations added over a long period of time. In contrast, some species are recorded in the live dataset that were not found in the dead assemblage, indicating the dead record is either incomplete (e.g. taphonomic change) or inadequately sampled.

We investigated the influence of patterns in cumulative increase on dead assemblages for sea-level reconstructions through the development of foraminiferal-based transfer functions. The cumulative transfer functions suggest that the performance improves during the first six sample intervals of the timeseries dataset with reconstruction differing by $1.2 \mathrm{~m}$ and remains constant thereafter.
\end{abstract}

\section{Keywords}

foraminifera, salt marsh, sea level, seasonal, UK

\section{Comments}

Postprint version. Published in Marine Micropaleontology, Volume 58, Issue 4, 2006, pages 287-315.

Publisher URL: http://dx.doi.org/10.1016/j.marmicro.2005.10.006 
Patterns in cumulative increase in live and dead species from foraminiferal time-series of Cowpen Marsh, Tees Estuary, UK: implications for sea-level studies

Benjamin P. Horton ${ }^{{ }^{*}}$ and John W. Murray ${ }^{2}$

${ }^{1}$ Sea Level Research Laboratory, Department of Earth and Environmental Science, University of Pennsylvania, Philadelphia, PA 19104-6316, USA.

${ }^{2}$ School of Ocean and Earth Science, National Oceanography Centre, European Way, Southampton, SO14 3ZH, UK.

* Corresponding author: Tel: 215573 5388; Fax: 215898 0964; E-mail: bphorton@sas.upenn.edu. 


\begin{abstract}
We have collected live and dead foraminiferal times-series data at two-weekly intervals for a twelve-month period from the intertidal zone of Cowpen Marsh, Tees Estuary, UK. The data from the 689 samples show profound differences between live and dead assemblages, although assemblages are dominated by just three species, Haynesina germanica, Jadammina macrescens and Trochammina inflata, which represent over $70 \%$ of the assemblage. The cumulative increase in species of most environments approximates to a log normal or log series. None of the datasets show a broken stick pattern. The cumulative maximum number of species, which represents the species carrying capacity of the environment, is recorded earlier in the life assemblages than the dead counterparts. The dead assemblage of Cowpen Marsh is found to have a higher abundance (435 compared to 163 individuals/10 $\mathrm{cm}^{3}$ ) and number of species (52 compared to 28) than its live counterpart because the dead assemblage represents many generations added over a long period of time. In contrast, some species are recorded in the live dataset that were not found in the dead assemblage, indicating the dead record is either incomplete (e.g. taphonomic change) or inadequately sampled.
\end{abstract}

We investigated the influence of patterns in cumulative increase on dead assemblages for sealevel reconstructions through the development of foraminiferal-based transfer functions. The cumulative transfer functions suggest that the performance improves during the first six sample intervals of the time-series dataset with reconstruction differing by $1.2 \mathrm{~m}$ and remains constant thereafter.

Keywords: foraminifera, saltmarsh, sea level, seasonal, UK 


\section{Introduction}

Most of the ecological studies of marsh foraminifera have been carried out with the aim of providing a contemporary database with which fossil foraminifera can be compared and interpreted (e.g. Scott, 1976; Scott and Medioli, 1978, 1980a, b; Scott and Leckie, 1980; Patterson, 1990; Gehrels, 1994; Guilbault et al., 1996; Goldstein and Watkins, 1998; Hayward et al., 1999, 2004; Horton, 1999; Horton et al., 1999a, b, 2003, 2005; Edwards and Horton, 2000; Hippensteel et al., 2000, 2002; Gehrels et al., 2001, Horton and Edwards, 2003, 2005, in press; Martin et al., 2003; Edwards et al., 2004a; Gehrels and Newman, 2004; Patterson et al., 2004; Culver and Horton, 2005; Tobin et al., 2005; Horton and Culver, in press). In terms of foraminiferal distributions within the intertidal zone, there is a clear distinction between an agglutinated assemblage that is restricted to the vegetated marsh and a calcareous assemblage that dominates the mudflats and sandflats of the intertidal zone. The agglutinated assemblage is commonly employed as a sea-level indicator in the production of sea-level index points (e.g. Scott and Medioli, 1978, 1980a; Williams 1989; Scott and Leckie, 1990; Thomas and Varekamp, 1991; Gehrels, 1994, 1999, 2000; Scott et al., 1995; de Rijk, 1995a, b; Gehrels et al., 2000, 2002; Hippensteel et al., 2000, 2002; Horton et al. 2000; Spencer, 2000; Edwards et al., 2004b; Horton and Edwards, 2005, in press; Boomer and Horton, in press; Edwards and Horton in press; Horton and Culver, in press). Saltmarsh foraminiferal zonation is a significantly more accurate indicator of sea level than undifferentiated marsh deposits because well-defined zones subdividing the marsh increase the vertical resolution of the deposits (Scott and Medioli, 1978).

In this paper we examine the difference between living and dead foraminiferal assemblages from the intertidal zone of Cowpen Marsh, Tees Estuary, UK, using time-series data and assess the significance of cumulative variability for sea-level reconstruction. Time-series data examine whether the same dominant and main subsidiary species are present on every sampling occasion. 
Furthermore, time series data record the occurrence of rare taxa that are continuously present in low numbers and also the arrivals and disappearances (Murray, 2003). Although time-series data are arduous to collect, clearly much is gained by making such studies. At present there are few such studies (Buzas et al., 1977, 2002; Scott and Medioli, 1980b; Murray, 1983, 2003; Basson and Murray, 1995; Hippensteel et al., 2000, 2002; Murray and Alve, 2000) and these are mainly confined to single environments such as intertidal and shallow sub-tidal. Murray (2003) states there is a need for further studies in a range of environments to provide estimates on the size of local species pools and to provide baseline data to compare future long-term environmental changes. This paper addresses the above by providing successive samples taken every two weeks for one year from the intertidal zone of Cowpen Marsh. In particular, we illustrate the cumulative increase of living and dead species from the high, middle and low marshes and tidal flat environments and assess the range and stability of species diversity measured by the SHE analyses during a twelve-month study. The reasons for doing this are that there are three possible relationships between the number of species $S$, the information function $H$ and evenness $E$ : broken stick, log normal or log series. Determination of the pattern for any given dataset describes both the structure of the natural population and allows predictions to be made about the number of species to be expected with an increase in sample size (Hayek and Buzas, 1997). SHE analysis allows recognition of faunal change either during time (Basson and Murray, 1995) or spatially (Buzas and Hayek, 1998). In addition, we investigate the significance of cumulative variability for sea-level reconstructions.

\section{Study Area}

Cowpen Marsh lies on the west side of the Tees estuary, which is located on the north-east coast of England, has a macro-tidal range $(4.6 \mathrm{~m})$ and forms a large proportion of the Tees lowlands (Figure 1). The marsh is a remnant of the once extensive areas of tidal flat now reclaimed for 
agricultural use. Extensive encroachment on the natural environment began in this area during the early part of the 18th century. The building of a seawall in 1740 effectively converted $85 \%$ of the original Cowpen Marsh into freshwater marsh with only the north-eastern corner remaining tidal. Modern Cowpen Marsh can be divided into high, middle and low marshes on the basis of the vascular flora (Figure 1). Approximately $90 \%$ of the marsh is high and middle marsh. The high marsh has the greatest number of floral species and is dominated by Elymus pycnanthus, Festuca ovina, Limonium vulgare, Orache spp., Plantago maritima and Sueada maritima. The number of species decreases at the transition between high and middle marsh (2.47 m above Ordnance Datum, the UK national vertical datum), with the latter dominated by Aster tripolium, Festuca ovina, Salicornia europaea and Sueada maritima. The transition to the low marsh (2.14 m OD) is marked by a further decrease in number with only two species remaining (Festuca ovina and Salicornia europaea).

\section{Methodology}

We established thirty-one stations along a transect from high marsh to mudflat, covering the intertidal zone from highest astronomical tide to below mean tide level. We placed stations where there were marked changes in topography or vegetation and levelled all stations to OD using an automatic level and staff. We collected samples at approximately two-weekly intervals for a twelve-month period between May 1995 and May 1996 although it was not possible to sample all stations on every occasion, particularly at the landward and seaward ends of the transect. Tables 1 and 2 show the number of stations samples in each floral zone and full documentation of the foraminiferal assemblages from every station are available online. Each sampling date coincided with a spring tide and timing of collection was standardised to approximately six hours after high tide. We took a standardised volume of $10 \mathrm{~cm}^{3}$ from each station $\left(10 \mathrm{~cm}^{2}\right.$ by $1 \mathrm{~cm}$ thick), thus allowing comparison between sampling stations. 
We prepared the foraminiferal sample following Scott and Medioli (1980a), de Rijk (1995a), Scott et al. (2001) and Horton and Edwards (in press). We placed each sample in buffered ethanol with the protein stain Rose Bengal added to identify organisms living at the time of collection (Walton, 1952). After staining, we wet-sieved each sample through $500 \mu \mathrm{m}$ and $63 \mu \mathrm{m}$ sieves and decanted. We examined the greater than $500 \mu \mathrm{m}$ and decanted fraction before being discarded. The taxonomy follows Horton and Edwards (in press). For foraminiferal time series analyses, we aggregated the data from the sampling stations of high (stations 1-5), middle (stations 6-14) and low (stations 15-18) marshes, and tidal flat (stations 19-31) environments following the vascular flora distributions (Figure 1).

There is much debate about which assemblage constituents to use for foraminifera population studies. Many researchers state that total foraminiferal population (life plus death) most accurately represents general environmental conditions because it integrates seasonal and temporal fluctuations (Buzas, 1968; Scott Medioli, 1980b; Scott and Leckie, 1990; Jennings et al., 1995; de Rijk, 1995a; Scott et al., 2001). However, Murray (1982, 1991, 2000) suggests that the use of total assemblages disregards taphonomic changes that will affect live assemblages after their death. Murray (1973) stated that only foraminiferal life assemblages can be used to determine ecology. Only detailed observation of the life assemblage over a considerable period of time can be used to determine all aspects of a population (Buzas, 1968). Horton et al.'s (2005) study of foraminiferal assemblages of the mangroves of Kaledupa indicates that the dead assemblage accurately represents the subsurface assemblages which are the focus of paleoenvironmental reconstructions, and furthermore that they do not show spatial and temporal fluctuations as much as the live assemblages. Importantly Horton (1999) and Horton and Edwards (2003, in press) indicate that the dead assemblages from British marshes, including Cowpen Marsh, are the most appropriate for paleoenvironmental studies because these assemblages 
closely resemble subsurface assemblages. These studies conclude that if the live assemblages are variable their combination with the dead assemblage to produce a total assemblage simply degrades the utility of the latter. Thus, in this paper we have only investigated the influence of cumulative increase on live and dead assemblages.

\subsection{Species diversity}

SHE is an acronym for the number of species $S$, information function $H$, and evenness $E$ (the extent to which individuals $N$ are equally distributed among species). SHE analysis was carried out using the procedures outlined by Buzas and Hayek (1996), Hayek and Buzas (1997) and Murray (2003).

\section{Foraminiferal time series of live assemblages}

The high marsh has the lowest number of species (10) of all environments and the lowest average standing crop (134 individuals $/ 10 \mathrm{~cm}^{3}$ ) of all marsh environments (Tables 1 and 2). The assemblage is dominated by agglutinated species Jadammina macrescens (67 individuals $/ 10 \mathrm{~cm}^{3}$ ) and Trochammina inflata (31 individuals $/ 10 \mathrm{~cm}^{3}$ ), but with a noticeable calcareous presence (e.g. Quinqueloculina spp.; 20 individuals $/ 10 \mathrm{~cm}^{3}$ ). Fig 2a shows the relative abundance of these species at high marsh Station 5 during the twelve month sampling period. Throughout the twelve months these species show large fluctuations. For example, Quinqueloculina spp. increases from $8 \%$ to $68 \%$ between $26^{\text {th }}$ August and $9^{\text {th }}$ September 1995 , and J. macrescens decreases from $100 \%$ to $22 \%$ between $5^{\text {th }}$ and $20^{\text {th }}$ January 1996 . The cumulative increase in number of species (Figure 3a) is relatively constant through time except for an acceleration between $22^{\text {nd }}$ November 1995 to $18^{\text {th }}$ February 1996 (6 to 9 species; 8692 to 10300 individuals), which is enhanced on the log series (Figure 3b). This relatively rapid change is further illustrated in the SHE measures of species diversity; InS, H, InE/InS and InE fluctuate throughout the high marsh dataset (Figure 
3c). This indicates that the pattern of distribution from the high marsh does not follow a broken stick, log series or log normal model.

The living dataset from the middle marsh environment of Cowpen Marsh are occupied by a cumulative total of 11 species during the 12 month study period. The middle marsh has a high average standing crop of individuals $\left(251\right.$ per $\left.10 \mathrm{~cm}^{3}\right)$. Similar to the high marsh, the middle marsh is dominated by agglutinated species (220 individuals $/ 10 \mathrm{~cm}^{3}$ ) such as $J$. macrescens, Miliammina fusca and T. inflata, with minor occurrences of calcareous species such as $H$. germanica and Quinqueloculina spp. For example, at Station 10 these agglutinated species contribute over $85 \%$ to the total assemblage. Within the twelve month study period, the relative abundance of $T$. inflata increases from $1^{\text {st }}$ May 1995 to $20^{\text {th }}$ January 1996 at the expense of $J$. macrescens and $M$. fusca. After $20^{\text {th }}$ January, the relative abundances of these species fluctuate (Figure 2b). The cumulative increase in species is initially static between the months of May and July 1995 (7 species). Thereafter, the number of species increases at a relatively constant rate until it reaches a plateau on $4^{\text {th }}$ February 1996 (Figure 4). Thus, the middle marsh dataset indicates that the time of maximum cumulative number of species, which is the carrying capacity of the environment, occurs after eight months. All SHE measures illustrate minor fluctuations during the 12 month study period (Figure 4c): InS and H show a steady increase; InE/InS is relatively constant, suggesting that the distribution follows log normal model; and InE shows no obvious patterns.

The living assemblage of the low marsh environment has a cumulative total of 16 species and 233 individuals $/ 10 \mathrm{~cm}^{3}$. In contrast to the high and middle marshes, the low marsh is dominated by calcareous species (209 individuals $/ 10 \mathrm{~cm}^{3}$ ). The major species are Elphidium earlandi, E. williamsoni and H. germanica and they dominate Station 17 (Figure 2c). These three calcareous 
species show steady state equilibria during the study period. Between $1^{\text {st }}$ May and $12^{\text {th }}$ June 1995 the cumulative number of species (Figure 5) is stationary (14 species), after which there are only two increases (12 ${ }^{\text {th }}$ to $28^{\text {th }}$ June 1995 and $10^{\text {th }}$ to $26^{\text {th }}$ August 1995$)$. Thus $26^{\text {th }}$ August marks the maximum cumulative number of species, less than four months into the twelve-month study. The SHE measures of diversity are relatively constant throughout the study period, although minor fluctuations are found in InS and InE in the months of June and August 1995 (Figure 5c). This implies that the distribution follows either a log normal or log series pattern.

The tidal flat has a high number of species (26), but the lowest standing crop (72 individuals $/ 10 \mathrm{~cm}^{3}$ ) of all environments and/or constituents. The assemblage is dominated by one calcareous species, H. germanica (37 individuals $/ 10 \mathrm{~cm}^{3}$ ), with minor influences from other calcareous species such as E. earlandi and E. williamsoni. This inference is supported by Figure 2d, which shows $H$. germanica dominating the assemblage during the twelve month study period except on $24^{\text {th }}$ October 1995 when there is a noticeable increase in relative abundance of $E$. williamsoni. This is associated with a very low standing crop (16 individuals $\left./ 10 \mathrm{~cm}^{3}\right)$. The cumulative number of species within the tidal flat increases from 9 to 26 at a constant rate for the first 3 months of the study period until the maximum number is reached on $10^{\text {th }}$ August 1995 (Figure 6). All measures of SHE analysis show some fluctuation in value during the first few sampling intervals. From $28^{\text {th }}$ June 1995 InS and H show a steady increase, InE/InS is constant, thus suggesting that the distribution follows log normal model, and InE shows a gradual decline (Figure 6c).

In summary, there are 112,067 live foraminifera from the 31 stations of Cowpen Marsh during the 12 month study which equates to an average standing crop of 163 individuals $/ 10 \mathrm{~cm}^{3}$. In total, 28 species were identified, however, the mixed agglutinated/calcareous assemblage is dominated by just three species (H. germanica, J. macrescens, Quinqueloculina spp. and T. inflata), which have 
a total count of 90,615 individuals and an average standing crop of 131 per $10 \mathrm{~cm}^{3}$. The cumulative number of species increases rapidly from 15 to a maximum of 28, which is reached on $10^{\text {th }}$ August 1995 (Figure 7). During the early months of the study H increases and other SHE values show relatively small oscillations. From the time of maximum cumulative number of species InE/InS remains constant, which indicates the distribution follows log normal model (Figure 7c).

\section{Foraminiferal time series of dead assemblages}

Seven species have been identified from the high marsh with a concentration of 432 individuals $/ 10 \mathrm{~cm}^{3}$; the lowest number of individuals in any environment (Tables 2 and 3). Moreover, the high marsh environment consists exclusively of agglutinated species (99\% of foraminifera) with $J$. macrescens (278 individuals $/ 10 \mathrm{~cm}^{3}$ ) and T. inflata (116 individuals $/ 10 \mathrm{~cm}^{3}$ ) dominating the assemblage. Figure 8a shows these two species dominating Station 5. During the sampling period the relative abundance of $J$. macrescens decreases from over $90 \%$ to less than $50 \%$ to be replaced by $T$. inflata. The cumulative number of species increases from 2 to 8 during

the twelve-month study period with two phases of expansion: 2 to 5 species between $12^{\text {th }}$ June 1995 and $10^{\text {th }}$ August 1995; and 5 to 7 species between $4^{\text {th }}$ February 1995 and $4^{\text {th }}$ April 2005 (Figure 9). During each phase of relative rapid change the InS increases whereas InE decreases. The other SHE measures ( $\mathrm{H}$ and $\mathrm{InE} / \mathrm{InS}$ ) show minor fluctuations after the first few measurements (Figure 9c). Thus, the dead assemblage of the high marsh does not conform to any of the three possible patterns of distribution.

The middle marsh has the highest concentration of individuals (549 per $10 \mathrm{~cm}^{3}$ ) of all environments and/or constituents with 15 species. Similar to the high marsh, the assemblage consists almost exclusively of agglutinated species which make up over $97 \%$ of the sum. The 
middle marsh is dominated by $J$. macrescens (373 individuals $/ 10 \mathrm{~cm}^{3}$ ), M. fusca (65 individuals $\left./ 10 \mathrm{~cm}^{3}\right)$ and $T$. inflata $\left(83\right.$ individuals $\left./ 10 \mathrm{~cm}^{3}\right)$. The dominance of these three species is supported by results from Station 10 (Figure 8b). J. macrescens shows a steady state equilibrium during the study period; however the relative abundance of $T$. inflata increases from $26^{\text {th }}$ August 1995 at the expense of $M$. fusca, which mirrors the results of the live assemblages. The cumulative increase in the number of species is relatively constant throughout the study period (Figure 10). The SHE values InS and InE increase and decrease through the study period, respectively. InE/InS remains relatively constant, as does $\mathrm{H}$ (Figure 10c). Thus, the distribution follows a log series or log normal pattern.

The low marsh consists of 19 species and 253 individuals $/ 10 \mathrm{~cm}^{3}$. The mixed agglutinated/calcareous assemblage is dominated by E. williamsoni, H. germanica and M. fusca. At Station 17, E. williamsoni and H. germanica show steady state equilibria, whereas $M$. fusca has relatively high relative abundances at the beginning and end of the study period (Figure 8c). The cumulative increase in the number of species is initially rapid and then slows reaching the maximum number by $20^{\text {th }}$ January 1996 (Figure 11). Such curves approximate to a log series. The trend of the SHE values in the low marsh mirror those of the middle marsh with InS and InE increasing and decreasing through the study period, respectively, and InE/InS and $\mathrm{H}$ relatively constant (Figure 11c).

The dead assemblages of the tidal flat have the highest number of species identified (52) of all environments and/or constituents. There is a cumulative total of 109,521 individuals with a concentration of 407 indivduals $/ 10 \mathrm{~cm}^{3}$. In this very diverse calcareous assemblage, only one species has a relative abundance greater than $10 \%$, H. germanica (183 individuals $\left./ 10 \mathrm{~cm}^{3}\right)$. At Station 24, the relative abundance of $H$. germanica remains static during the study period (Figure 8d). The cumulative number of species increases at a steady rate during the study period, perhaps 
reaching the maximum number of species late in the study period (19 ${ }^{\text {th }}$ March 1996) (Figure 12). The InE/InS remains constant during the study period, suggesting a log normal pattern of species distribution (Figure 12c).

To summarize, there are 52 dead species and cumulative total of 299,823 dead foraminifera from the 31 stations of Cowpen Marsh taken during the 12 month study, which equates to a concentration of 435 individuals per $10 \mathrm{~cm}^{3}$ sample. The predominately agglutinated $(60 \%)$ assemblage is dominated by three species $J$. macrescens, $T$. inflata and calcareous $H$. germanica, which have a concentration of 302 individuals $/ 10 \mathrm{~cm}^{3}$. The cumulative number of species increases rapidly from 27 to 49 by $24^{\text {th }}$ September 1995 , after which the increase is gradual to the maximum number of 52 is reached on the $19^{\text {th }}$ March 1996 (Figure 13). The SHE values, InS and InE increase and decrease through the study period, respectively. InE/InS remains relatively constant, whereas $\mathrm{H}$ shows a slight oscillation (Figure 13c). The SHE values and pattern of increase in the cumulative number indicates the dead assemblage follows a log series or log normal model.

\section{Discussion}

This study shows similarities and differences between life and dead assemblages within the intertidal zone of Cowpen Marsh and its floral environments (Tables 2, 4). Despite their differing number of species and individuals, the assemblages of the live and dead assemblages are dominated by just three species: the calcareous taxon $H$. germanica, which dominates the low marsh and tidal flat environments; and the agglutinated taxa J. macrescens and T. inflata that are found in marsh environments. In total these species contribute $70 \%$ to the assemblage. Other studies using either total (live plus dead) or dead assemblages have documented similar assemblages in other temperate marshes of the UK (e.g. Coles, 1977; Coles and Funnell, 1981; 
Boomer, 1998; Funnell and Boomer, 1998; Haslett et al., 1997; Horton et al., 1999; Gehrels et al. 2001; Horton and Edwards, 2005, in press), Europe (e.g. Phleger, 1970; Pujos, 1976; le Campion, 1970; Murray, 1991; Gehrels and Newman, 2004) and North America (e.g. Scott, 1976; Scott and Medioli, 1978, 1980a, b; Patterson, 1990; Gehrels, 1994, 1999, 2000, Spencer, 2000; Guilbault et al., 1996; Hippensteel et al., 2000, 2002; Gehrels et al., 2000, 2002, in press; Martin et al., 2003; Edwards et al., 2004a, b; Patterson et al., 2004; Culver and Horton, 2005; Tobin et al., 2005; Horton and Culver, in press;), and tropical mangroves (e.g. Brönnimann, et al. 1992; Brönnimann and Whittaker 1993; Haslett, 2001; Horton et al., 2003, 2005).

There are pronounced differences between live and dead assemblages (Table 4). Murray (1991) noted that it is frequently observed that the living and dead assemblages from the same sample differ to a greater or lesser extent. This is not surprising, for the living assemblage represents only the time of sampling or as Buzas (1968, p. 11) states “...a single frame of a motion picture...”. Thus, the living assemblage may or may not be in equilibrium with its environment and may or may not be typical of living assemblages over a longer period of time. In contrast, the dead assemblage represents many generations added over a long period of time, that is, it is time averaged. Thus, the dead assemblage of Cowpen Marsh is found to have a higher abundance (435 individuals $/ 10 \mathrm{~cm}^{3}$ compared to 163 individuals) and number of individuals (52 compared to 28 species). It is common that the species diversity of a dead foraminiferal assemblage is greater than that of the living assemblage from the same sample unless postmortem losses have altered the former or the sedimentation rate is high (Murray, 2003). Murray’s (1983, 1987, 2003) studies of the Exe estuary illustrated that the vast majority of increases in number and species of the dead datasets compared to the living is due to transport of shelf taxa. This is illustrated in the tidal flat environment of Cowpen Marsh. The dead assemblages have a substantially higher number of species (52 compared to 26), individuals (109,521 compared to 19,459) and concentrations (407 compared to 72 individuals $/ 10 \mathrm{~cm}^{3}$ ) than the live assemblages through the transport of dead tests 
into the study area. Twenty-three of new dead forms are shelf taxa that cling to firm substrates such as seaweeds, tunicates, shells and rocks, in areas subject to disturbance and hence may be transported in intertidal zones (Murray, 1979).

In contrast, three species (Cornuspira selseyensis, Elphidium macellum and Quinqueloculina oblonga) recorded living from the intertidal zone of the study area during the twelve-months were not found in the dead assemblage. Thus, the dead record is either incomplete, was inadequately sampled or perhaps are recent introductions, which have yet to produce a record of dead tests or were transported out of the study area. Likewise, Murray’s (1983, 1987, 2003) study of the Exe estuary illustrated the appearance of living taxa that were not transferred into the dead assemblage.

It is thought the dead assemblage of Cowpen Marsh gives a time-averaged record and thus, it has the potential to define the maximum number of species likely to be identified (Murray, 2003). However, the dead assemblage differs from the live assemblages from which it was drawn through taphonomic changes. For instance, the dead assemblages of the marsh environments have a higher agglutinated:calcareous ratio compared to the live assemblages (11:1 and 6:1, respectively). Such a change in ratio is due to the loss through dissolution of calcareous species in the acidic marsh environments (e.g. Green and other, 1993). Horton (1999) determined the pH of the marsh environment of Cowpen Marsh to be less than 6.1. For example, 1928 cumulative live individuals of Quinqueloculina spp. were found in the high marsh environment compared to 320 cumulative dead individuals. Similar differences between live and dead assemblages due to the dissolution of calcareous species have been noted in other studies (e.g. von Daniels, 1970; Goldstein and Harben, 1993; Goldstein et al., 1995; Collins, 1996; Goldstein and Watkins, 1998, 1999; Edwards and Horton, 2000; Horton et al., 2005; Culver and Horton, 2005). With respect to sea-level studies, Edwards and Horton (2000) noted during a study of Arne Peninsula, South 
England, that reconstruction techniques performed reliably in the high marsh zone where agglutinated foraminiferal species are dominant. However, in lower marsh environments where calcareous species are prevalent, post-mortem test dissolution alters the fossil assemblages and leaves them without modern analogues. Thus, to circumvent this problem, Edwards and Horton (2000) had to develop new reconstruction techniques based on agglutinated foraminifera and utilising preserved test linings.

Von Daniels (1970) in a study of the Lim Channel, Croatia, noted substantial taphonomic effects, both dissolution of calcareous forms, such as thin walled Nonionella opima, and instability of the cement in certain agglutinated forms such as Adercotryma led to the loss of tests. Goldstein and Watkins (1998, 1999), Collins (1996) and Culver and Horton (2005) also recorded significant taphonomic changes in agglutinated foraminifera. Goldstein and Watkins $(1998,1999)$ indicated that M. fusca, Ammotium spp. and Pseudothurammina limnetes were less likely to be preserved than other agglutinated taxa as a result of bacterial degradation of the cements holding agglutinated particles together. They also described "half tests" of M. fusca, Arenoparrella mexicana and Trochammina spp. and attributed this to metazoan predation, possibly by fiddler crabs (Goldstein and Watkins, 1999). Similar half-tests were observed in by Culver and Horton (2005) in North Carolina marsh material, and fiddler crabs are abundant in this region. However, breakage of tests can also occur during processing and so predation may not be the cause of this mode of preservation. Culver and Horton (2005) also illustrated that Tiphotrocha comprimata, which is quite abundant live, is not found in the dead assemblage. Thus, this species suffers selective, rapid (and complete) loss of tests very soon after death at this site (or else is a recent introduction). In contrast, this study of Cowpen Marsh has good preservation of agglutinated foraminifera. Similar preservation of marsh foraminifera in the more northerly locations of Maine, USA (e.g. Gehrels, 1994, 1999, 2000, Gehrels et al., 2000, 2002) and Nova Scotia, 
Canada (Scott and Medioli, 1978, 1980a, b; Tobin et al., 2005) has been attributed to less extensive bioturbation.

\subsection{Implications for sea-level studies}

Horton and Edwards (2005, in press) have developed a transfer function or biotic index to reconstruct former sea levels based upon the statistically significant relationship between foraminiferal dead assemblages and elevation with respect to the tidal frame for 15 study sites with Great Britain and Ireland. They developed a predictive foraminiferal-based transfer function using weighted averaging partial least squares regression and calibration (ter Braak and Juggins, 1993; Birks, 1995; Juggins, 2004). We have used the same statistical methodology on the

foraminiferal dead assemblages collected from Cowpen Marsh over the twelve-month study period to assess the implications for studies of Holocene sea-level change. The scatter graphs of two-weekly cumulative transfer functions (Figure 14) show a strong linear relationship between observed and foraminiferal-predicted elevations $\left(r^{2}>0.81\right)$ supporting the conclusions of Horton and Edwards (2003, 2005, in press) that precise reconstructions of former sea levels are possible.

The accuracy of the monthly transfer functions, however, varies during the course of the year. Figure 15 clearly shows the performance of the model improves during the first six sample intervals (01/05/1995 to 12/07/1995) where $\mathrm{r}^{2}$ increases from 0.81 to 0.96 and root means squared error of prediction (RMSEP) deceases from 0.40 to 0.18 . Thereafter, the statistical measures that assess the performance of the model remain constant.

These cumulative variations of transfer functions have important implications for sea-level reconstructions. To illustrate this we have applied the cumulative transfer functions separately to calibrate the fossil assemblages from core CM1 and the resulting reconstructions compared. The calibration process assigns an elevation to each sample in metres with respect to paleo-mean tide 
level to each fossil sample (known as a reference water level). The fossil sequence at Cowpen Marsh is characteristic of many UK saltmarsh paleoenvironments, with alternations between peats and silty peats (Figure 16). Agglutinated species (e.g. J. macrescens and T. inflata) dominate the peat samples, indicating a saltmarsh environment. In the silty peats, percentage frequencies of agglutinated species fall, reflecting the increased abundance of calcareous taxa. The assemblage becomes dominated by $H$. germanica and Elphidium species, and is indicative of low marsh, estuarine or tidal flat environments.

The cumulative foraminiferal-based transfer functions reproduce a broadly similar pattern of elevation change that reflects the changes in foraminiferal assemblages (Figure 17). The maximum elevation occurs within the peat, associated with the agglutinated, saltmarsh foraminifera, and is indicative of deposition above local MHWST (2.65 m OD). On closer examination of Figure 17, however, the reconstructions fluctuate from 01/05/1995 to 12/07/1995 at the same time as the performance statistics were variable, particularly with reconstructed reference water levels below $2.4 \mathrm{~m}$ OD. Of potentially great significance is the fact that reconstructed elevations produced by the cumulative transfer function differ during the first six sampling intervals by as much as $1.2 \mathrm{~m}$. This cumulative effect is due to variations in the reconstructed elevational optima and tolerances of individual foraminiferal species along the Cowpen Marsh transect. The optimum and tolerance of a species are its weighted average and standard deviation, respectively. Therefore, at a site with a particular elevation, species with their optima for elevation close to the site will tend to be the most abundant present. Figures 14, 15 and 17 suggest there is a noticeable improvement in the precision and accuracy of reconstructions if six or more measurements are made. These variations could be due sample size, utility of surface assemblages or problems inherent in sampling strategy. Some controversy exists concerning the statistically correct number of counts required for quantitative examinations, particularly the effect of variations in the number of species between samples and the significance 
of varying fractional abundances on the reliability of results (e.g. Patterson and Fishbein, 1989; Buzas, 1990; Bennett, 1994; Hayek and Buzas, 1997; Fatela and Taborda, 2002). However, the methodology of Horton and Edwards (2005, in press) lessens this error as it removes all samples that have counts of less than 100 individuals and all species groups that contribute less than $5 \%$ of any assemblage (Patterson and Fishbein, 1989; Fatela and Taborda, 2002).

Hippensteel et al. (2002) and Martin et al. (2003) suggest that surface assemblages (e.g. 0-1, 0-2 $\mathrm{cm}$ ) are not necessarily the best analogs for palaeoreconstruction. They indicate that dead assemblages are subject to test inputs from infaunal populations as they pass through the surface mixed layers. Results from other temperate marshes are seemingly contradictory. Goldstein et al. (1995) found living foraminifera to a depth of $30 \mathrm{~cm}$ in Georgia marshes. On the other hand, Horton (1999) and Culver and Horton (2005) found living and dead assemblages of Cowpen Marsh and Outer Banks, North Carolina, respectively, did not differ significantly with depth. In Canada, Patterson et al. (2004) found assemblages from 0-1 cm in New Brunswick marshes produced statistically reliable results, whereas only those from $0-10 \mathrm{~cm}$ in Vancouver marshes produced reliable result because of infaunal habitats and taphonomic biasing. Tobin et al. (2005) concluded otherwise; they admitted the existence of infaunal populations but denied that they had significant effect on the formation of death assemblages.

We believe the variations in transfer function are due to problems inherent in sampling strategy. The poor accuracy coincides with the late spring and early summer months of sampling, which coincides with maximum relative abundance of calcareous species. Figure 18 shows the ratio of agglutinated to calcareous species for marsh and tidal flat environments is greater than 1 from $10^{\text {th }}$ August 1995 to $19^{\text {th }}$ March 1996. Horton and Edwards (2003) showed the elevation tolerances of the principal calcareous species (e.g. H. germanica, E. williamsoni and Quinqueloculina spp.) are greater than $0.32 \mathrm{~m}$. In contrast, the agglutinated species (e.g. J. macrescens, M. fusca and T. 
inflata) have relatively small altitudinal ranges with tolerances below $0.29 \mathrm{~m}$. Therefore, the transfer function becomes more stable when the cumulative dataset consists of samples taken in late summer, autumn, winter and early spring when the influence of agglutinated taxa is greater. This inference is supported by Horton and Edwards's (2003) investigation of contemporary foraminiferal dead distribution using cluster analysis. They concluded that an investigation of contemporary saltmarsh foraminifera that recovers a complete set of samples in the winter, spring, summer, and autumn (i.e. four samples per year), will provide the best quality data for use in sea-level investigations. If only one set of measurements can be obtained, sampling in the winter months may represents the most reliable alternative.

\section{Conclusions}

We have collected live and dead foraminiferal times-series data at two-weekly intervals for a twelve-month period from the intertidal zone of Cowpen Marsh, Tees Estuary, UK; this equates to 689 samples, 55 species and 411,890 individuals. The data show profound differences between life and dead assemblages, although assemblages are dominated by just three species, the calcareous taxon H. germanica and the agglutinated taxa J. macrescens and T. inflata.

The cumulative increase in species from the time series dataset of all environments, except the high marsh (shows no obvious pattern), follows a pattern that approximates to a log series or log normal. None of the datasets show a broken stick pattern. The cumulative maximum number of species, which represents the species carrying capacity of the environment, is recorded earlier in the live assemblages than the dead counterparts. Furthermore, the dead assemblage of Cowpen Marsh is found to have a higher abundance (435 compared to 163 individuals $/ 10 \mathrm{~cm}^{3}$ ) and number of species (52 compared to 28) than its live counterpart, because the dead assemblage represent many generations added over a longer period of time. This is illustrated in the tidal flat where 
twenty-three shelf taxa have undergone post-mortem transport into the environment. In contrast, three species recorded living from the intertidal zone of the study area during the 12 months were not found in the dead assemblage, and the live assemblage of the high marsh recorded a larger number of species (10 compared to 7). Thus, the dead record is either incomplete (e.g. taphonomic change), was inadequately sampled, or perhaps are recent introductions which have yet to produce a record of dead tests or were transported out of the study area.

We investigated the influence of patterns in cumulative increase on dead assemblages for sealevel reconstructions through the development of foraminiferal-based transfer functions. The cumulative transfer functions suggest that precise reconstructions of former sea levels are possible. However, the performance of the transfer function improves during the first six sampling intervals of the time-series dead dataset, remaining constant thereafter. These cumulative variations have important implications for sea-level reconstructions as the reconstructed elevations differ by up to $1.2 \mathrm{~m}$.

\section{Acknowledgements}

This research was carried out under a special topic award from the National Environment Research Council (Contract number GST/02/0761). Special acknowledgements are given to H. J. B. Birks, D. S. Brew, A. J. Long, and I. Shennan for their help and advice, comments and suggestions. It is a contribution to IGCP Project 495 "Quaternary Land-Ocean Interactions: Driving Mechanisms and Coastal Responses.” 


\section{REFERENCES}

Bartenstein, H., Brand, E., 1938. Die Foramniferen Fauna des Jade-Gebiete. 1. Jadammina polystoma n. g., n. sp. sus dem Jade-Gebiete (For.). Senckenbergiana, 20, 381-385.

Basson, J.W., Murray, J.W., 1995. Temporal variations in four species of intertidal foraminifera, Bahrain, Arabian Gulf. Micropaleontology, 41, 69-76.

Bennett, K.D., 1994. Confidence intervals for age estimates and deposition times in lateQuaternary sediment sequences. The Holocene, 4, 337-348.

Birks, H.J.B., 1995. Quantitative palaeoenvironmental reconstructions. In: Maddy, D., Brew, J. (Eds.), Statistical modelling of Quaternary science data, Technical Guide No. 5 ed, Quaternary Research Association, Cambridge, pp. 161-236.

Boomer, I., 1998. The relationship between meiofauna (Ostracoda, Foraminifera) and tide levels in modern intertidal environments of North Norfolk: a tool for palaeoenvironmental reconstruction. Bulletin of the Geological Society of Norfolk, 46, 17-29.

Boomer, I., Horton, B.P., in press. Holocene relative sea-level movements along the North Norfolk Coast, UK. Palaeogeography, Palaeoclimatology, Palaeoecology.

ter Braak, C.J.F., Juggins, S., 1993. Weighted averaging partial least squares regression (WAPLS): an improved method for reconstructing environmental variables from species assemblages. Hydrobiologia, 269/270, 485-502.

Brady, H. B., 1870. Foraminifera, in Brady, G. S., Robertson, D., and Brady, H.B., The Ostracoda and foraminifera of tidal rivers. Annals and Magazine of Natural History, Series 4, v. 6, p. 273-306.

Brönnimann, P., Whittaker, J.E., 1984a. A lectotype for Jadammina macrescens (Brady) and emendation of Jadammina Bartenstein and Brand (Protozoa: Foraminiferida). Bulletin of the British Museum (Natural History), Zoology Series, 46, 303-309. 
Brönnimann, P., Whittaker, J.E., 1984b. A neotype for Trochammina inflata (Montagu) with notes on the wall structure (Protozoa : Foraminiferida). Bulletin of the British Museum (Natural History), (Zoology Series), 46, 311-315.

Brönnimann, P., Whittaker, J.E., 1993. Taxonomic revision of some recent agglutinated foraminifera from the Malay Archipelago in the Millett Collection. Bulletin of the Natural History Museum, London (Zoology), 59, 107-124.

Brönnimann, P., Whittaker, J.E., Zaninetti, L., 1992. Brackish water foraminifera from mangrove sediments of southwestern Viti Levu, Fiji Islands, Southwest Pacific. Revue de Paléobiologie, 11, 13-65.

Buzas, M.A., 1968. On the spatial distribution of foraminifera. Contributions from Cushman foundation for Foraminiferal Research, 19, 1-11.

Buzas, M. A., 1990. Another look at confidence limits for species proportions. Journal of Paleontology, 64, 842-843.

Buzas, M.A., Hayek, L.C., 1996. Biodiversity resolution: an integrated approach. Biodiversity Research, 3, 40-43.

Buzas, M.A., and Hayek, L.E.C. 1998. SHE analysis for biofacies identification. Journal of Foraminiferal Research, 28, 233-239.

Buzas, M.A., Smith, R. K., Beem, K. A., 1977. Ecology and systemmatics of foraminifera in two Thalassia habitats, Jamaica, West Indies. Smithsonian Contributions Paleobiology, 31, 1139.

Buzas, M.A., Hayak, L.-A.C., Reed, S.A., Jett, J.A., 2002. Foraminiferal densities over five years in the Indian River Lagoon, Florida: A model of pulsating patches. Journal of Foraminiferal Research, 32, 68-92.

Le Campion, J., 1970. Contribution à l'étude des foraminifères du Bassin d' Arcachon et du proche océan. Bulletin de l' Institut Géologique du Bassin d’Aquitaine, 8, 3 -98. 
Coles, B.P.L., 1977. The Holocene foraminifera and palaeogeography of central Broadland. Unpublished Ph.D. Dissertation, University of East Anglia.

Coles, B.P.L., Funnell, B.M., 1981. Holocene paleoenvironments of Broadland, England. Special Publication of the International Association of Sedimentologists, 5, 123-131.

Collins, E.S., 1996. Marsh-estuarine benthic foraminiferal distributions and Holocene sea-level reconstructions along the South Carolina coastline. Unpublished PhD thesis, Dalhousie University.

Culver, S.J., Horton, B.P., 2005. Infaunal foraminifera from the Outer Banks, North Carolina, USA. Journal of Foraminiferal Research, 35, 148-170.

Cushman, J. A., 1936. Some new species of Elphidium and related genera. Contributions from the Cushman Laboratory for Foraminiferal Research, 12, 78-89.

Cushman, J.A., 1947. New species and varieties of foraminifera from off the southeastern coast of the United States. Contributions from the Cushman Laboratory of Foraminiferal Research, 32, 86-92.

Cushman, J. A., Brönnimann, P., 1948. Additional new species of arenaceous foraminifera from shallow waters of Trinidad. Contributions from the Cushman Laboratory for Foraminiferal Research, 24, 37-43.

Edwards, R.J., Horton, B.P., 2000. High Resolution Records of Relative Sea-Level Change from U.K: Salt-marsh Foraminifera. Marine Geology, 169, 41-56.

2Edwards, R.J., Horton, B.P., in press. Developing High Resolution Records of Relative SeaLevel Change Using A Microfossil Transfer Function: An Example from North Norfolk, UK. Royal Society Special Publication.

Edwards, R.J., Wright, A.J., van de Plassche, O., 2004a. Surface distributions of salt-marsh foraminifera from Connecticut, USA: Modern analogues for high resolution sea-level studies. Marine Micropaleontology, 51, 1-21. 
Edwards, R.J., van de Plassche, O., Gehrels, W.R., Wright, A.J., 2004b. Assessing sea-level data from Connecticut, USA, using a foraminiferal transfer function for tide level. Marine Micropaleontology, 51, 239-255.

Ehrenberg, C. G., 1840. Eine weitere Erläuterung des Organismus mehrerer in Berlin lebend beobachterer Polythalamien der Nordsee. Bericht über die zur Bekanntmachung geeigneten Verhandlungen der Königlichen Preussischen Akademie der Wissenschaften zu Berlin, v. for 1840, p. 18-23.

Fatela, F., Taborda, R., 2002. Confidence limits of species proportions in microfossil assemblages. Marine Micropaleontology, 45, 169-174.

Funnell, B.M., Boomer, I., 1998. Microbiofacies tidal-level and age deduction in Holocene saltmarsh deposits on the North Norfolk Coast. Bulletin of the Geological Society of Norfolk, 46, 31-55.

Gehrels, W.R., 1994. Determining relative sea-level change from saltmarsh foraminifera and plant zones on the coast of Maine, USA. Journal of Coastal Research, 10, 990-1009.

Gehrels, W.R., 1999. Middle and late Holocene sea-level changes in eastern Maine reconstructed from foraminiferal saltmarsh stratigraphy and AMS 14C dates on basal peat. Quaternary Research, 52, 350-359.

Gehrels, W.R., 2000. Using foraminiferal transfer functions to produce high-resolution sea-level records from salt-marsh deposits, Maine, USA. The Holocene, 10, 367-376.

Gehrels, W.R., Newman, R.M., 2004. Salt-marsh foraminifera in Ho Bugt, western Denmark, and their use as sea-level indicators. Geografisk Tidsskrift, 104, 97-106.

Gehrels, W.R., Belknap, D. F., Black, S., Newnham, R. M., 2002. Rapid sea-level rise in the Gulf of Main, USA since AD1800. The Holocene, 10, 367-376.

Gehrels, W.R., Roe, H. M., Charman, D. J., 2001. Foraminifera, testate amoebae and diatoms as sea-level indicators in UK saltmarshes: a quantitative multiproxy approach. Journal of Quaternary Science, 16, 201-220. 
Goldstein, S.T., Harben, E.B., 1993. Taphofacies implications of infaunal foraminiferal assemblages in a Georgia saltmarsh, Sapelo Island. Micropaleontology, 39, 55-62.

Goldstein, S.T., Watkins, G.T., 1998. Elevation and the distribution of salt-marsh foraminifera, St. Catherine’s Island, Georgia: a taphonomic approach. Palaios, 13, 570-580.

Goldstein, S.T., Watkins, G.T., 1999. Taphonomy of salt marsh foraminifera: an example from coastal Georgia. Paleogeography, Palaeoclimatology, Palaeoecology, 149, 103-114.

Goldstein, S.T., Watkins, G.T., Kuhn, R.M., 1995. Microhabitats of salt marsh foraminifera: St. Catherines Island, Georgia, USA. Micropaleontology, 26, 17-29.

Green, M.A., Aller, R.C., Aller, J.Y., 1993. Carbonate dissolution and temporal abundances of foraminifera in Long Island Sound sediments. Limnology and Oceanography, 38, 331345.

Guilbault, J., Clague, J.J., Lapointe, M., 1996. Foraminiferal evidence for the amount of coseismic subsidence during a late Holocene earthquake on Vancouver Island, west coast of Canada. Quaternary Science Reviews, 15, 913-937.

Haslett, S.K., Davies, P., Strawbridge, F. 1997. Reconstructing Holocene sea-level change in the Severn Estuary and Somerset Levels: the foraminifera connection. Archaeology in the Severn Estuary, 8, 29-40.

Haslett, S.K., 2001. The Palaeoenvironmental implications of the distribution of intertidal foraminifera in a tropical Australian estuary: a reconnaissance study. Australian Geographical Studies, 39, 67-74.

Hayek, L.C., Buzas, M.A., 1997. Surveying Natural Populations. Columbia University Press, New York, 563 pp.

Haynes, J. R., 1973. Cardigan Bay Recent Foraminifera (Cruises of the R.V. Antur, 1962-1964). Bulletin of the British Museum (Natural History), (Zoology Series), Supplement 4, p. 1245. 
Hayward, B.W., Reid, C.M., Scott, D.B., 1999. Tidal range of marsh foraminifera for determining former sea-level heights in New Zealand. New Zealand Journal of Geology and Geophysics, 42, 395-413.

Hayward, B.W., Scott, G.H., Grenfell, H.R., Carter, R., Lipps, J.H., 2004a. Techniques for estimation of tidal elevation and confinement ( salinity) histories of sheltered harbours and estuaries using benthic foraminifera: examples from New Zealand. The Holocene, $14,218-232$.

Heron-Allen, E., Earland, A., 1909. On the recent and fossil foraminifera of the shore-sands at Selsey Bill, Sussex. Part 11. Journal of the Royal Microscopical Society, 306-336.

Hippensteel, S.P., Martin, R.E., Nikitina, D., Pizzuto, J.E., 2000. The formation of Holocene marsh foraminiferal assemblages, middle Atlantic Coast, USA: implications for the Holocene sea-level change. Journal of Foraminiferal Research, 30, 272-293.

Hippensteel, S.P., Martin, R.E., Nikitina, D., Pizzuto, J.E., 2002. Interannual variation of marsh foraminiferal assemblages (Bombay Hook National Wildlife Refuge, Smyrna, DE): Do foraminiferal assemblages have a memory? Journal of Foraminiferal Research, 32, 97109.

Horton, B.P., 1999. The contemporary distribution of intertidal foraminifera of Cowpen Marsh, Tees Estuary, UK: implications for studies of Holocene sea-level changes. Palaeogeography, Palaeoclimatology, Palaeoecology Special Issue, 149, 127-149.

Horton, B.P., Culver, S.J., in press. Modern intertidal foraminifera of the Outer Banks, North Carolina, USA and their applicability for sea-level studies. Journal of Coastal Research.

Horton, B.P., Edwards, R.J., 2003. Seasonal distributions of foraminifera and their implications for sea-level studies. SEPM (Society for Sedimentary Geology) Special Publication, 75, 21-30.

Horton, B.P., Edwards, R.J., 2005. The application of local and regional transfer functions to reconstruct former sea levels, North Norfolk, England. The Holocene, 15, 216-228. 
Horton, B.P., Edwards, R.J., in press. Quantifying Holocene Sea Level Change Using Intertidal Foraminifera: Lessons from the British Isles. Journal of Foraminiferal Research Special Publication.

Horton, B.P., Edwards, R.J., Lloyd, J.M., 1999a. UK intertidal foraminiferal distributions: Implications for sea-level studies. Marine Micropaleonotology, 36, 205-223.

Horton, B.P., Edwards, R.J., Lloyd, J.M., 1999b. Reconstruction of former sea levels using a foraminiferal-based transfer function. Journal of Foraminiferal Research, 29, 117-129.

Horton, B.P., Edwards, R.J., Lloyd, J.M., 2000. Implications of a microfossil transfer function in Holocene sea-level studies. In Shennan, I. and Andrews, J.E., (Eds.), Holocene landocean interaction and environmental change around the western North Sea, Geological Society Special Publication, 166, pp. 41-54.

Horton, B.P., Larcombe, P., Woodroffe, S. A., Whittaker, J. E., Wright, M. W., Wynn, C., 2003. Contemporary foraminiferal distributions of the Great Barrier Reef coastline, Australia. implications for sea-level reconstructions. Marine Geology, 3320, 1-19.

Horton, B.P., Thomson, K., Woodroffe, S.E., Whittaker, J.E., Wright, M.R., 2005. Contemporary foraminiferal distributions, Wakatobi National Park, Southeast Sulawesi, Indonesia. Journal of Foraminiferal Research, 35, 1-14.

Jennings, A.E., Nelson, A.R., Scott, D.B., Arevena, J.C., 1995. Marsh foraminifera assemblages in the Valdiva estuary, south-central Chile, relative to vascular plants and sea level. Journal of Coastal Research, 11, 107-123.

Juggins, S., 2004. C2, Version 1.4. University of Newcastle.

Kornfeld, M.M., 1931. Recent littoral foraminifera from Texas and Louisiana. Contributions from the Department of Geology of Stanford University, 1, 77-101.

Martin, R.E., Hippensteel, S.P., Nikitina, D., Pizzuto, J.E., 2003. Taphonomy and artificial timeaveraging of marsh foraminiferal assemblages (Bombay Hook National Wildlife Refuge, 
Smyrna, Delaware, U.S.A.): Implications for rates and magnitudes of late Holocene sealevel change: SEPM (Society for Sedimentary Geology) Special Publication, 75, 31-40.

Montagu, G. 1803. Testacea Britannica, Romsey, 606 p.

Montagu, G., 1808. Supplement to Testacea Britannica. S. Woolmer, Exeter, 183 p.

Murray, J.W., 1971. An atlas of British Recent foraminiferids. Heinemann Educational Books, London, 244 p.

Murray, J.W., 1973. Distribution and ecology of living foraminiferids. Heinemann Educational Books, London. 274 p.

Murray, J.W., 1979. British nearshore foraminiferids. Academic Press, London, 68 p.

Murray, J.W., 1982. Benthic foraminifera: the validity of living, dead or total assemblages for the interpretation of palaeoecology. Journal of Micropaleontology, 1, 137-140.

Murray, J.W., 1983. Population dynamics of benthic foraminifera: results from the Exe estuary, England. Journal Foraminiferal Research, 13, 1-12.

Murray, J.W., 1987. Biogenic indicators of suspended sediment transport in marginal marine environments: quantitative examples from SW Britain. Journal of Geological Society London, 144, 127-133.

Murray, J.W., 1991. Ecology and palaeoecology of benthic foraminifera. Longman Scientific and Technical, Harlow, England, 397 p.

Murray, J.W., 2000. JFR Comment: The enigma of the continued use of total assemblages in ecological studies of benthic foraminifera. Journal of Foraminiferal Research, 30, 244245.

Murray, J.W., 2003. Patterns in cumulative increase in species form foraminiferal time-series. Marine Micropaleontology, 48, 1-21.

Murray, J.W., Alve, E., 2000. Major aspects of foraminifera variability (standing crop and biomass) on a monthly scale in an intertidal zone. Journal of Foraminiferal Research, 30, 177-191. 
Patterson, R. T., 1990. Intertidal benthic foraminifera biofacies on the Fraser River Delta, British Columbia. Micropaleontology, v. 36, p. 229-244.

Patterson, R.T., Fishbein, E., 1989. Re-examination of the statistical methods used to determine the number of point counts needed for micropaleontological quantitative research. Journal of Paleontology, 63, 245-248.

Patterson, R.T., Gehrels, W.R., Belknap, D.F., Dalby, A.P., 2004. The distribution of salt marsh foraminifera at Little Dipper Harbour New Brunswick, Canada: implications for development of widely applicable transfer functions in sea-level research. Quaternary International, 120, 185-194.

Phleger, F. B., 1970. Foraminiferal populations and marine marsh processes. Limnology and Oceanography, 15, 522-534.

Pujos, M., 1976. Ecologie des foraminifères benthiques et des thécamoebiens de la Gironde et au plateau continental Sud-Gascogne. Application à la connaissance du Quaternaire terminal de la région Ouest-Gironde. Memoires de l’Institut de Géologie du Bassin d’Aquitaine, 8, $1-274$.

de Rijk, S., 1995a. Salinity control on the distribution of salt marsh Foraminifera (Great Marshes, Massachusetts). Journal of Foraminiferal Research, 25, 156-166.

de Rijk, S., 1995b. Salinity control on the distribution of salt marsh Foraminifera (Great Marshes, Massachusetts). Journal of Foraminiferal Research, 25, 156-166.

Scott, D.B., 1976. Brackish-water foraminifera from Southern California and description of Polysaccammina ipohalina n. gen., n. sp. Journal of Foraminiferal Research, 6, 312-321.

Scott, D.B., Medioli, F.S., 1978. Vertical zonation of marsh foraminifera as accurate indicators of former sea levels. Nature, 272, 528-531.

Scott, D.B., Medioli, F.S., 1980a. Quantitative studies of marsh foraminifera distribution in Nova Scotia: Implications for sea-level studies. Journal of Foraminiferal Research Special Publication, 17, 1-58. 
Scott, D.B., Medioli, F.S., 1980b. Living vs. total foraminifera populations: Their relative usefulness in paleoecology. Journal of Paleontology, 54, 814-831.

Scott, D.B., Brown, K., Collins, E.S., Medioli, F.S., 1995. A new sea-level curve from Nova Scotia: evidence for a rapid, acceleration of sea-level in the late mid-Holocene. Canadian Journal of Earth Sciences, 32, 2071-2080.

Scott, D.B., Medioli, F.S., Schafer, C.T., 2001. Monitoring in coastal environments using foraminifera and thecamoebian indicators. Cambridge University Press, Cambridge, 177p.

Scott, D.K., Leckie, R.M., 1990. Foraminiferal zonation of Great Sippwissett Salt Marsh (Falmouth, Massachusetts). Journal of Foraminiferal Research, 20, 248-266.

Spencer, R.S., 2000. Foraminiferal assemblages from a Virginia saltmarsh, Phillips Creek, Virginia. Journal of Foraminiferal Research, 30, 143-155.

Thomas, E., Varekamp, J.C., 1991. Palaeoenvironmental analysis of marsh sequences (Clifton, Connecticut): Evidence for punctuated rise in relative sea-level during the Holocene. Journal of Coastal Research Special Issue, 11, 125-158.

Tobin, R., Scott, D.B., Collins, E.S., Medioli, F. S., 2005. Infaunal benthic foraminifera in some North American marshes and their influence on fossil assemblages. Journal of Foraminiferal Research, 35, 130-147.

von Daniels, C.H., 1970. Quantitative ökologische Analyse der zeitlichen und räumlichen Verteilung rezenter Foraminiferen im Limski kanal bei Rovinj (nördliche Adria). Göttinger Arb. Geol. Paläontol. 8, 1-109.

Walton, W. R., 1952, Techniques for recognition of living foraminifera. Contributions from Cushman foundation for Foraminiferal Research, 3, 56-60.

Williams, H.F.L., 1989, Foraminiferal zonations on the Fraser River Delta and their application to paleoenvironmental interpretations. Palaeogeography, Palaeoclimatology, Palaeoecology, 73, 39-50. 


\section{Tables}

Table 1. Cumulative increase in standing crop (SC) and species (Spp.) in living foraminifera over 12 months from the high, middle and low marshes, tidal flat and intertidal zone. The number of stations sampled in each environment are also shown.

Table 3. Cumulative increase in individuals per $10 \mathrm{~cm}^{3}$ (IND) and species (Spp.) in dead foraminifera over 12 months from the high, middle and low marshes, tidal flat and intertidal zone. The number of stations sampled in each environment are also shown.

Table 2. The dominant and subsidiary live and dead foraminiferal taxa.

Table 4. Summary of the datasets of live and dead assemblages. 


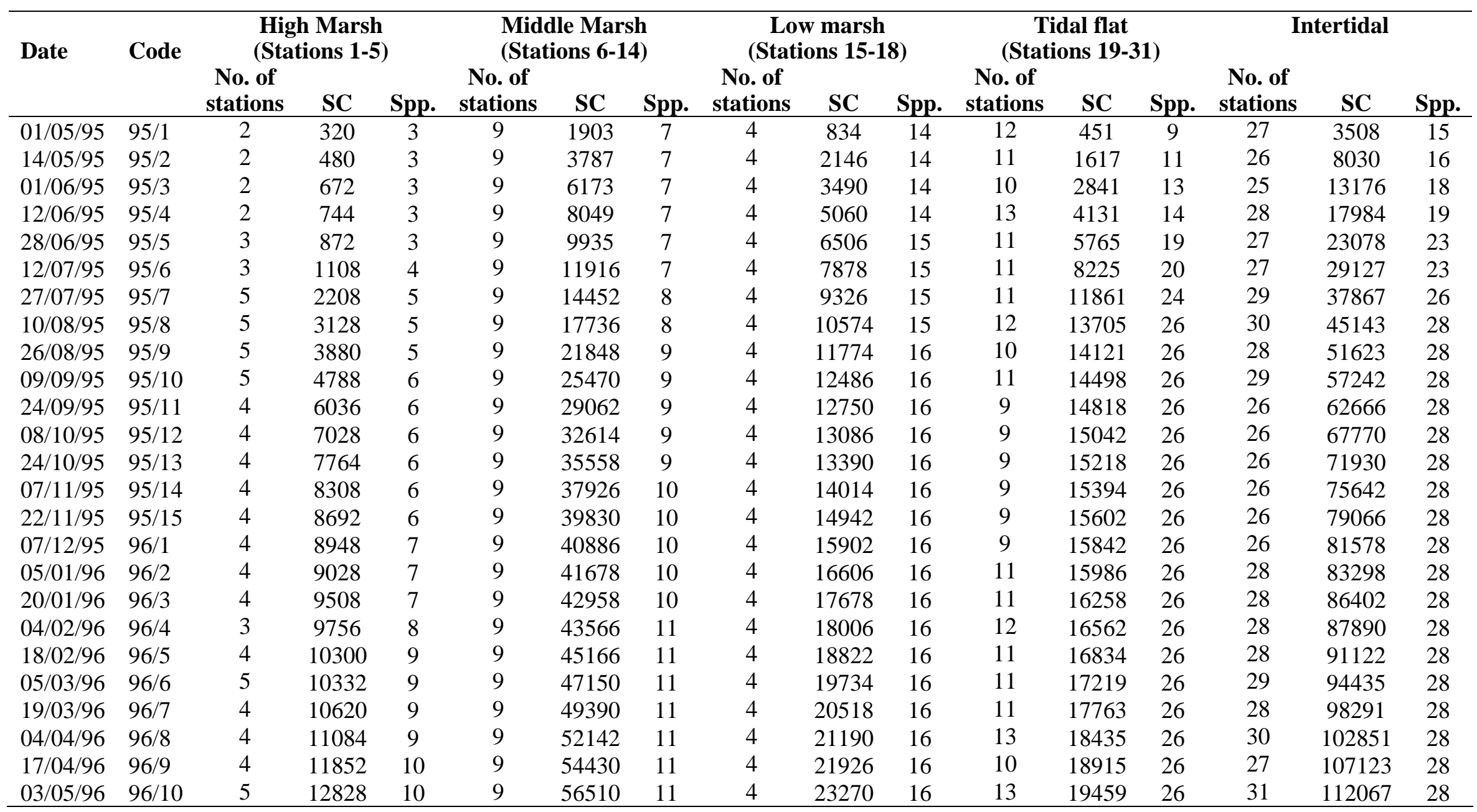

Table 1 


\begin{tabular}{|c|c|c|c|}
\hline Environment & Parameter & Live & Dead \\
\hline \multirow{7}{*}{ Intertidal } & No. of species & 28 & 52 \\
\hline & No. of individuals & 112067 & 299823 \\
\hline & No. of stations sampled & 689 & 689 \\
\hline & Standing crop/individuals per $10 \mathrm{~cm}^{3}$ & 163 & 435 \\
\hline & $\begin{array}{l}\text { Date of cumulative maximum } \\
\text { number of species }\end{array}$ & 10/08/95 & $19 / 03 / 96$ \\
\hline & Species recorded each month & $7-18$ & $17-32$ \\
\hline & Pattern of distribution & Log normal & Log series/normal \\
\hline \multirow[t]{7}{*}{ High marsh } & No. of species & 10 & 7 \\
\hline & No. of individuals & 12828 & 41448 \\
\hline & No. of stations sampled & 96 & 96 \\
\hline & Standing crop/individuals per $10 \mathrm{~cm}^{3}$ & 134 & 432 \\
\hline & $\begin{array}{l}\text { Date of cumulative maximum } \\
\text { number of species }\end{array}$ & $17 / 04 / 96$ & 04/04/96 \\
\hline & Species recorded each month & $1-6$ & $2-6$ \\
\hline & Pattern of distribution & None & None \\
\hline \multirow[t]{7}{*}{ Middle marsh } & No. of species & 11 & 15 \\
\hline & No. of individuals & 56510 & 123555 \\
\hline & No. of stations sampled & 225 & 225 \\
\hline & Standing crop/individuals per $10 \mathrm{~cm}^{3}$ & 251 & 549 \\
\hline & $\begin{array}{l}\text { Date of cumulative maximum } \\
\text { number of species }\end{array}$ & 04/02/96 & 03/05/96 \\
\hline & Species recorded each month & $4-8$ & $4-11$ \\
\hline & Pattern of distribution & Log normal & Log series/normal \\
\hline \multirow[t]{7}{*}{ Low marsh } & No. of species & 16 & 19 \\
\hline & No. of individuals & 23270 & 25299 \\
\hline & No. of stations sampled & 100 & 100 \\
\hline & Standing crop/individuals per $10 \mathrm{~cm}^{3}$ & 233 & 253 \\
\hline & $\begin{array}{l}\text { Date of cumulative maximum } \\
\text { number of species }\end{array}$ & 26/8/95 & 20/01/96 \\
\hline & Species recorded each month & $5-14$ & $6-16$ \\
\hline & Pattern of distribution & Log series/normal & Log series \\
\hline \multirow[t]{7}{*}{ Tidal flat } & No. of species & 26 & 52 \\
\hline & No. of individuals & 19459 & 109521 \\
\hline & No. of stations sampled & 269 & 269 \\
\hline & Standing crop/individuals per $10 \mathrm{~cm}^{3}$ & 72 & 407 \\
\hline & $\begin{array}{l}\text { Date of cumulative maximum } \\
\text { number of species }\end{array}$ & $10 / 8 / 95$ & $19 / 03 / 96$ \\
\hline & Species recorded each month & $2-15$ & $14-28$ \\
\hline & Pattern of distribution & Log normal & Log normal \\
\hline
\end{tabular}

Table 2 


\begin{tabular}{|c|c|c|c|c|c|c|c|c|c|c|c|c|c|c|c|c|}
\hline \multirow[t]{2}{*}{ Date } & \multirow[t]{2}{*}{ Code } & \multicolumn{3}{|c|}{ High Marsh } & \multicolumn{3}{|c|}{ Middle Marsh } & \multicolumn{3}{|c|}{ Low marsh } & \multicolumn{3}{|c|}{ Tidal flat } & \multicolumn{3}{|c|}{ Intertidal } \\
\hline & & $\begin{array}{c}\text { No. of } \\
\text { stations }\end{array}$ & IND & Spp. & $\begin{array}{c}\text { No. of } \\
\text { stations }\end{array}$ & IND & Spp. & $\begin{array}{c}\text { No. of } \\
\text { stations }\end{array}$ & IND & Spp. & $\begin{array}{c}\text { No. of } \\
\text { stations }\end{array}$ & IND & Spp. & $\begin{array}{c}\text { No. of } \\
\text { stations }\end{array}$ & IND & Spp. \\
\hline $01 / 05 / 95$ & $95 / 1$ & 2 & 720 & 2 & 9 & 7028 & 7 & 4 & 1112 & 12 & 12 & 4370 & 25 & 27 & 13230 & 27 \\
\hline $14 / 05 / 95$ & $95 / 2$ & 2 & 1200 & 2 & 9 & 12900 & 8 & 4 & 2712 & 13 & 11 & 11798 & 30 & 26 & 28610 & 33 \\
\hline 01/06/95 & $95 / 3$ & 2 & 1752 & 2 & 9 & 18598 & 8 & 4 & 4056 & 15 & 10 & 18018 & 30 & 25 & 42424 & 33 \\
\hline $12 / 06 / 95$ & $95 / 4$ & 2 & 2072 & 2 & 9 & 25622 & 8 & 4 & 5176 & 15 & 13 & 27524 & 36 & 28 & 60394 & 39 \\
\hline 28/06/95 & $95 / 5$ & 3 & 2662 & 3 & 9 & 31968 & 8 & 4 & 6038 & 16 & 11 & 35412 & 39 & 27 & 76080 & 41 \\
\hline $12 / 07 / 95$ & $95 / 6$ & 3 & 3562 & 3 & 9 & 37988 & 8 & 4 & 6858 & 16 & 11 & 44065 & 40 & 27 & 92473 & 41 \\
\hline 27/07/95 & $95 / 7$ & 5 & 6538 & 5 & 9 & 44916 & 11 & 4 & 8606 & 16 & 11 & 56169 & 41 & 29 & 116225 & 42 \\
\hline $10 / 08 / 95$ & $95 / 8$ & 5 & 8854 & 5 & 9 & 50410 & 11 & 4 & 9670 & 16 & 12 & 62969 & 44 & 30 & 131903 & 45 \\
\hline $26 / 08 / 95$ & $95 / 9$ & 5 & 10566 & 5 & 9 & 55434 & 11 & 4 & 10870 & 16 & 10 & 65867 & 45 & 28 & 142737 & 46 \\
\hline 09/09/95 & $95 / 10$ & 5 & 12008 & 5 & 9 & 60003 & 11 & 4 & 11722 & 16 & 11 & 68769 & 45 & 29 & 152502 & 45 \\
\hline $24 / 09 / 95$ & $95 / 11$ & 5 & 13544 & 5 & 9 & 65363 & 11 & 4 & 12130 & 17 & 9 & 70944 & 48 & 26 & 161981 & 49 \\
\hline 08/10/95 & $95 / 12$ & 4 & 14968 & 5 & 9 & 69891 & 11 & 4 & 12866 & 18 & 9 & 73296 & 48 & 26 & 171021 & 49 \\
\hline 24/10/95 & $95 / 13$ & 4 & 16295 & 5 & 9 & 73619 & 11 & 4 & 13682 & 18 & 9 & 75168 & 48 & 26 & 178764 & 49 \\
\hline 07/11/95 & $95 / 14$ & 4 & 17799 & 5 & 9 & 77427 & 12 & 4 & 14594 & 18 & 9 & 77296 & 48 & 26 & 187116 & 49 \\
\hline $22 / 11 / 95$ & $95 / 15$ & 4 & 19735 & 5 & 9 & 81859 & 12 & 4 & 15650 & 18 & 9 & 79376 & 48 & 26 & 196620 & 49 \\
\hline 07/12/95 & $96 / 1$ & 4 & 21655 & 5 & 9 & 86355 & 13 & 4 & 17058 & 18 & 9 & 81616 & 48 & 26 & 206684 & 49 \\
\hline 05/01/96 & $96 / 2$ & 4 & 23847 & 5 & 9 & 91299 & 13 & 4 & 18210 & 18 & 11 & 84096 & 49 & 28 & 217452 & 49 \\
\hline $20 / 01 / 96$ & $96 / 3$ & 4 & 26503 & 5 & 9 & 96323 & 14 & 4 & 19154 & 19 & 11 & 86272 & 50 & 28 & 228252 & 50 \\
\hline $04 / 02 / 96$ & $96 / 4$ & 3 & 28215 & 5 & 9 & 102003 & 14 & 4 & 20178 & 19 & 12 & 88656 & 50 & 28 & 239052 & 50 \\
\hline $18 / 02 / 96$ & $96 / 5$ & 4 & 31415 & 6 & 9 & 106579 & 14 & 4 & 20978 & 19 & 11 & 91713 & 50 & 28 & 250685 & 50 \\
\hline 05/03/96 & $96 / 6$ & 5 & 35128 & 6 & 9 & 111123 & 14 & 4 & 21779 & 19 & 11 & 95249 & 50 & 29 & 263279 & 50 \\
\hline $19 / 03 / 96$ & $96 / 7$ & 4 & 36584 & 6 & 9 & 114659 & 14 & 4 & 22595 & 19 & 11 & 99089 & 52 & 28 & 272927 & 52 \\
\hline $04 / 04 / 96$ & $96 / 8$ & 4 & 37832 & 7 & 9 & 117555 & 14 & 4 & 23606 & 19 & 13 & 103953 & 52 & 30 & 282943 & 52 \\
\hline $17 / 04 / 96$ & $96 / 9$ & 4 & 39304 & 7 & 9 & 120195 & 14 & 4 & 24547 & 19 & 10 & 107409 & 52 & 27 & 291455 & 52 \\
\hline $03 / 05 / 96$ & $96 / 10$ & 5 & 41448 & 7 & 9 & 123555 & 15 & 4 & 25299 & 19 & 13 & 109521 & 52 & 31 & 299823 & 52 \\
\hline
\end{tabular}

Table 3 


\begin{tabular}{|c|c|c|c|c|}
\hline \multirow[t]{2}{*}{ Environment } & \multicolumn{2}{|c|}{ Live } & \multicolumn{2}{|c|}{ Dead } \\
\hline & Dominant species & Subsidiary species & Dominant species & Subsidiary species \\
\hline Intertidal & $\begin{array}{l}\text { Haynesina germanica } \\
\text { Jadammina macrescens } \\
\text { Trochammina inflata }\end{array}$ & $\begin{array}{l}\text { Elphidium williamsoni } \\
\text { Quinqueloculina spp. }\end{array}$ & $\begin{array}{l}\text { Haynesina germanica } \\
\text { Jadammina macrescens } \\
\text { Trochammina inflata }\end{array}$ & Miliammina fusca \\
\hline High marsh & $\begin{array}{l}\text { Jadammina macrescens } \\
\text { Trochammina inflata } \\
\text { Quinqueloculina spp. }\end{array}$ & & $\begin{array}{l}\text { Jadammina macrescens } \\
\text { Trochammina inflata }\end{array}$ & \\
\hline Middle marsh & $\begin{array}{l}\text { Jadammina macrescens } \\
\text { Trochammina inflata }\end{array}$ & & $\begin{array}{l}\text { Jadammina macrescens } \\
\text { Miliammina fusca } \\
\text { Trochammina inflata }\end{array}$ & \\
\hline Low marsh & $\begin{array}{l}\text { Elphidium earlandi } \\
\text { Elphidium williamsoni } \\
\text { Haynesina germanica }\end{array}$ & $\begin{array}{l}\text { Jadammina macrescens } \\
\text { Quinqueloculina seminulum } \\
\text { Quinqueloculina spp. }\end{array}$ & $\begin{array}{l}\text { Elphidium williamsoni } \\
\text { Haynesina germanica } \\
\text { Jadammina macrescens } \\
\text { Miliammina fusca }\end{array}$ & Quinqueloculina spp. \\
\hline Tidal flat & Haynesina germanica & $\begin{array}{l}\text { Elphidium williamsoni } \\
\text { Elphidium earlandi } \\
\text { Quinqueloculina oblonga } \\
\text { Quinqueloculina seminulum }\end{array}$ & Haynesina germanica & Stainforthia fusiformis \\
\hline
\end{tabular}

Table 4. 


\section{Figures}

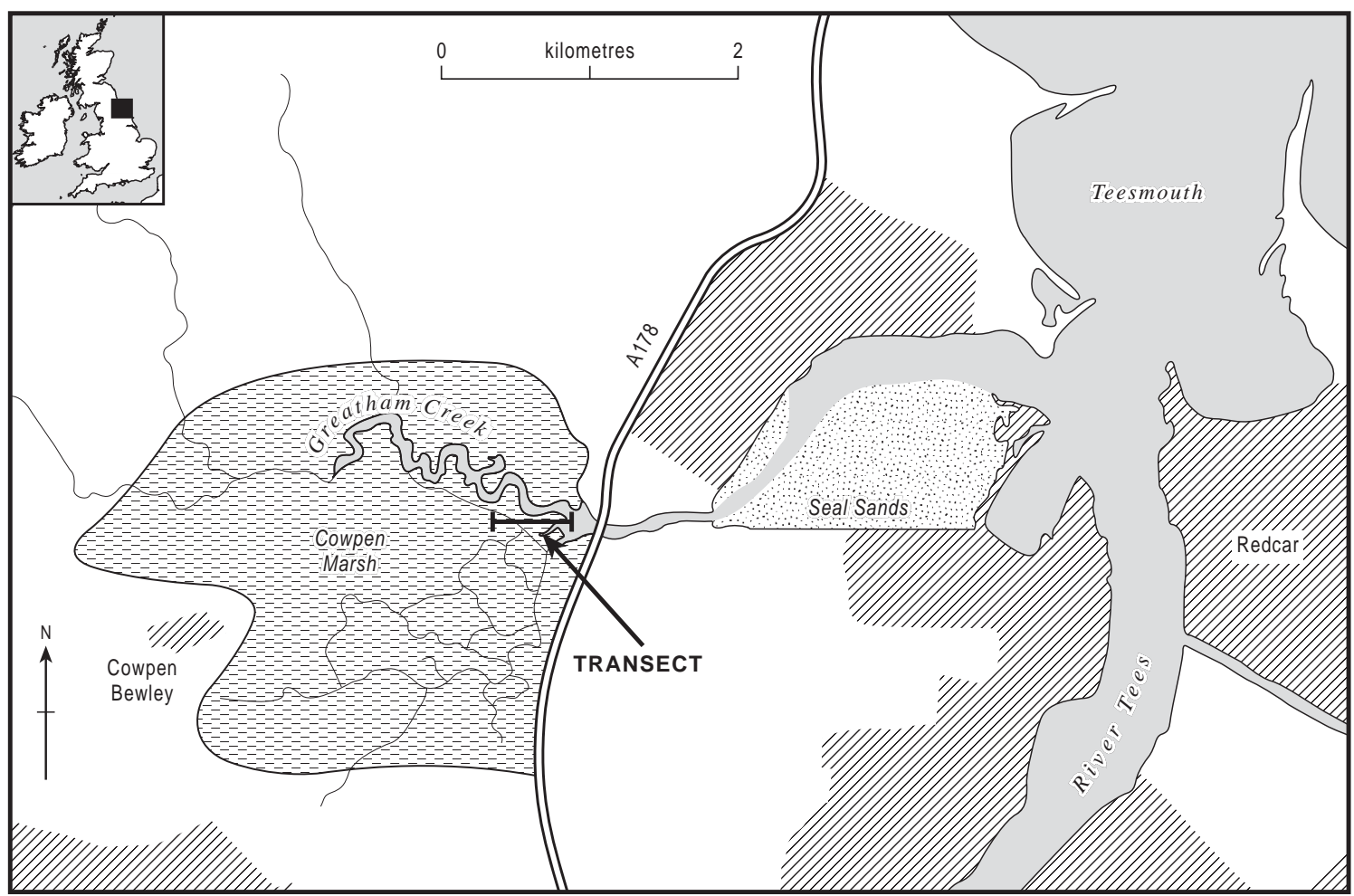

High marsh

Elymus pycnanthus

Festuca ovina

Limonium vulgare

Orache spp.

Plantago maritima

Sueada maritima

Middle marsh

Aster tripolium

Festuca ovina

Saliornia europaea

Sueada maritima

Low marsh

Festuca ovina

Saliornia europaea

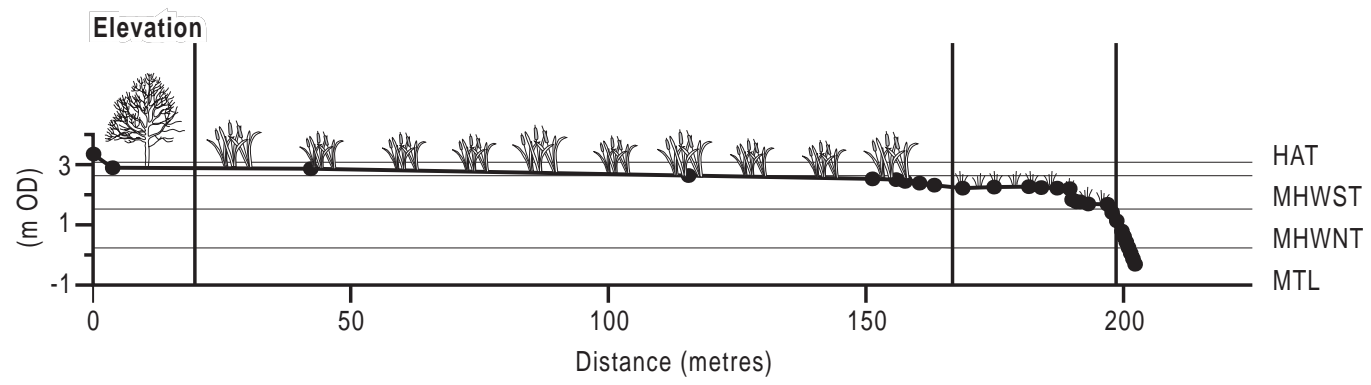

Fig. 1 Location map of Cowpen Marsh, Tees Estuary, UK showing contemporary sampling transect and floral zones. 


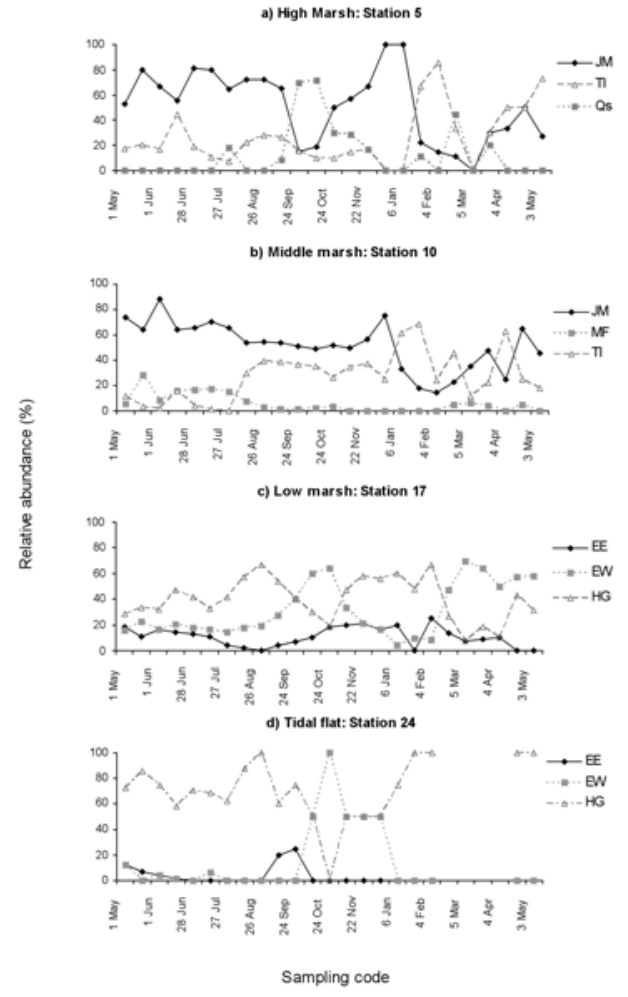

Fig. 2 Relative abundance of the dominant live species during the twelve month study period from (a) high, (b) middle and (c) low marshes and (d) tidal flat environments. Species abbreviation: $\mathrm{EW}=$ Elphidium williamsoni $\mathrm{HG}=$ Haynesina germanica; $\mathrm{JM}=$ Jadammina macrescens; $\mathrm{MF}=$ Miliammina fusca. 

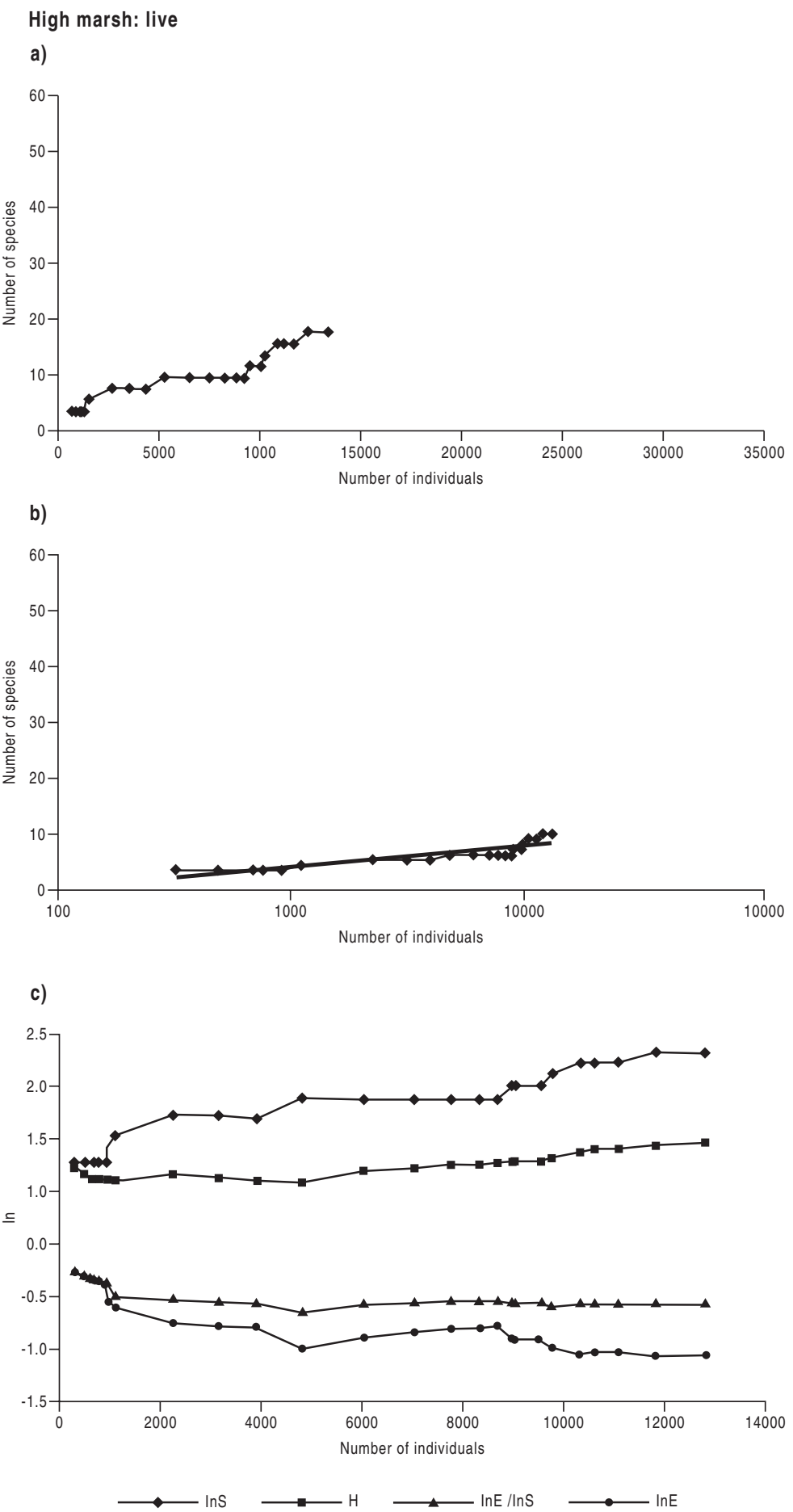

Fig. 3 (a) Cumulative increase in species and standing crop in living foraminifera over 12 months from the high marsh (b) with logarithmic scale (the straight line is the log series trend line) and (c) SHE analysis. 
Middle marsh: live

a)

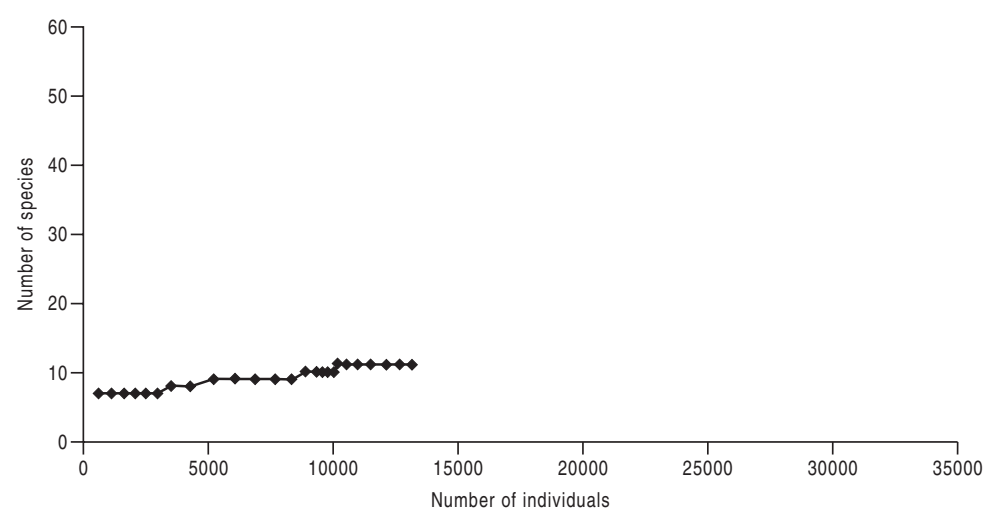

b)

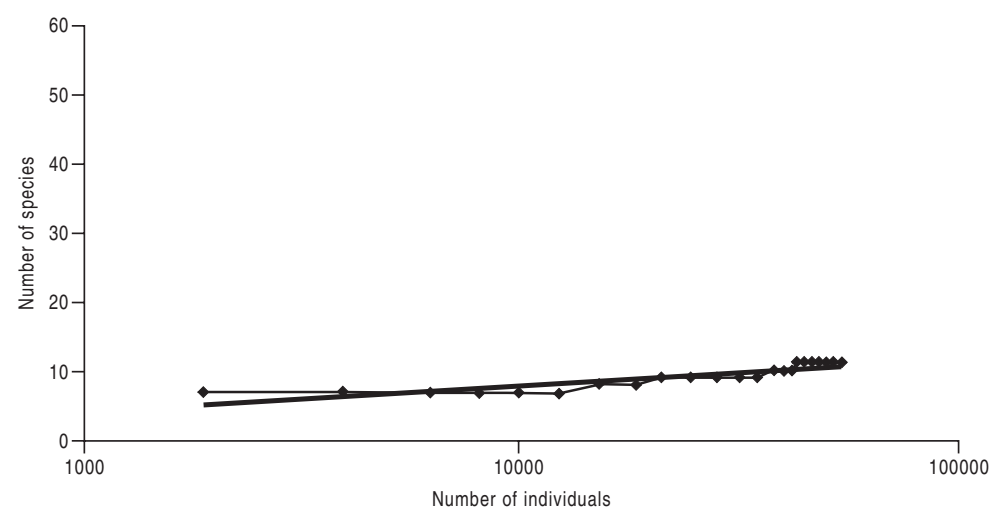

c)

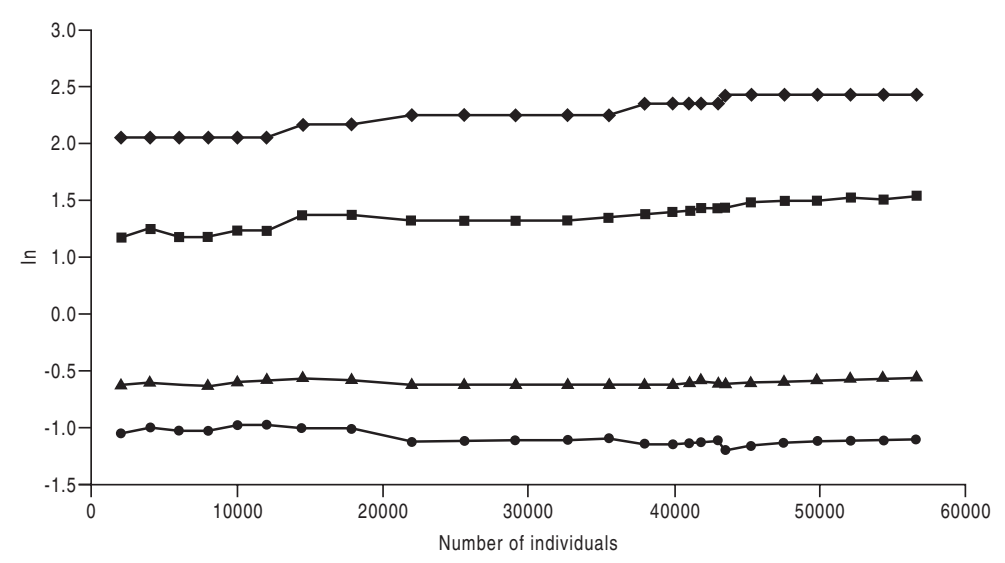

$\longrightarrow \ln S \longrightarrow \ln \longrightarrow \ln S \longrightarrow \ln E$

Fig. 4 (a) Cumulative increase in species and standing crop in living foraminifera over 12 months from the middle marsh (b) with logarithmic scale (the straight line is the log series trend line) and (c) SHE analysis. 
Low marsh: live
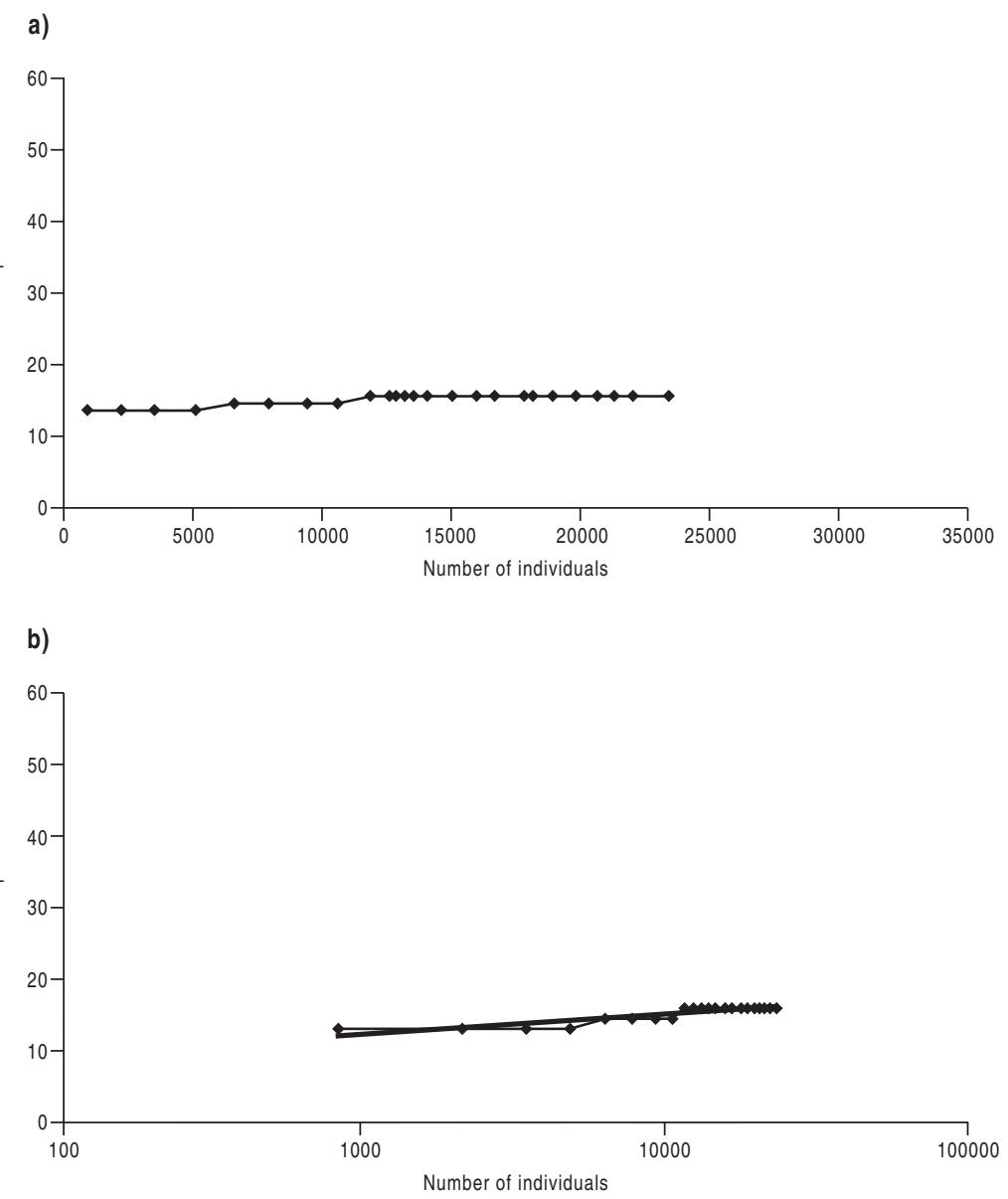

c)

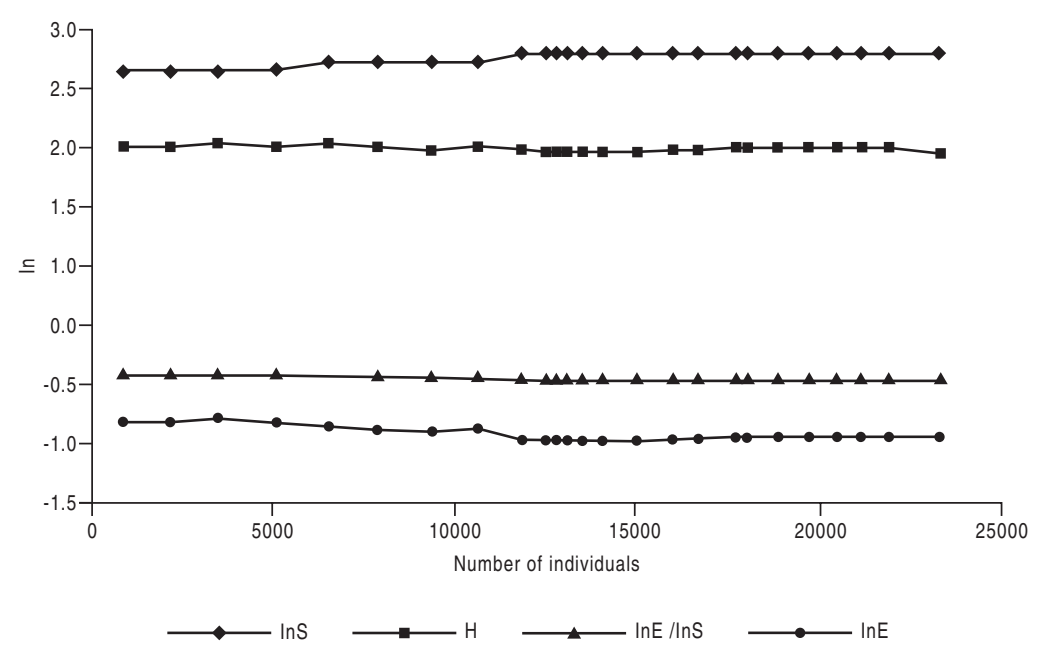

Fig. 5 (a) Cumulative increase in species and standing crop in living foraminifera over 12 months from the low marsh (b) with logarithmic scale (the straight line is the log series trend line) and (c) SHE analysis. 
Tidal flat: live
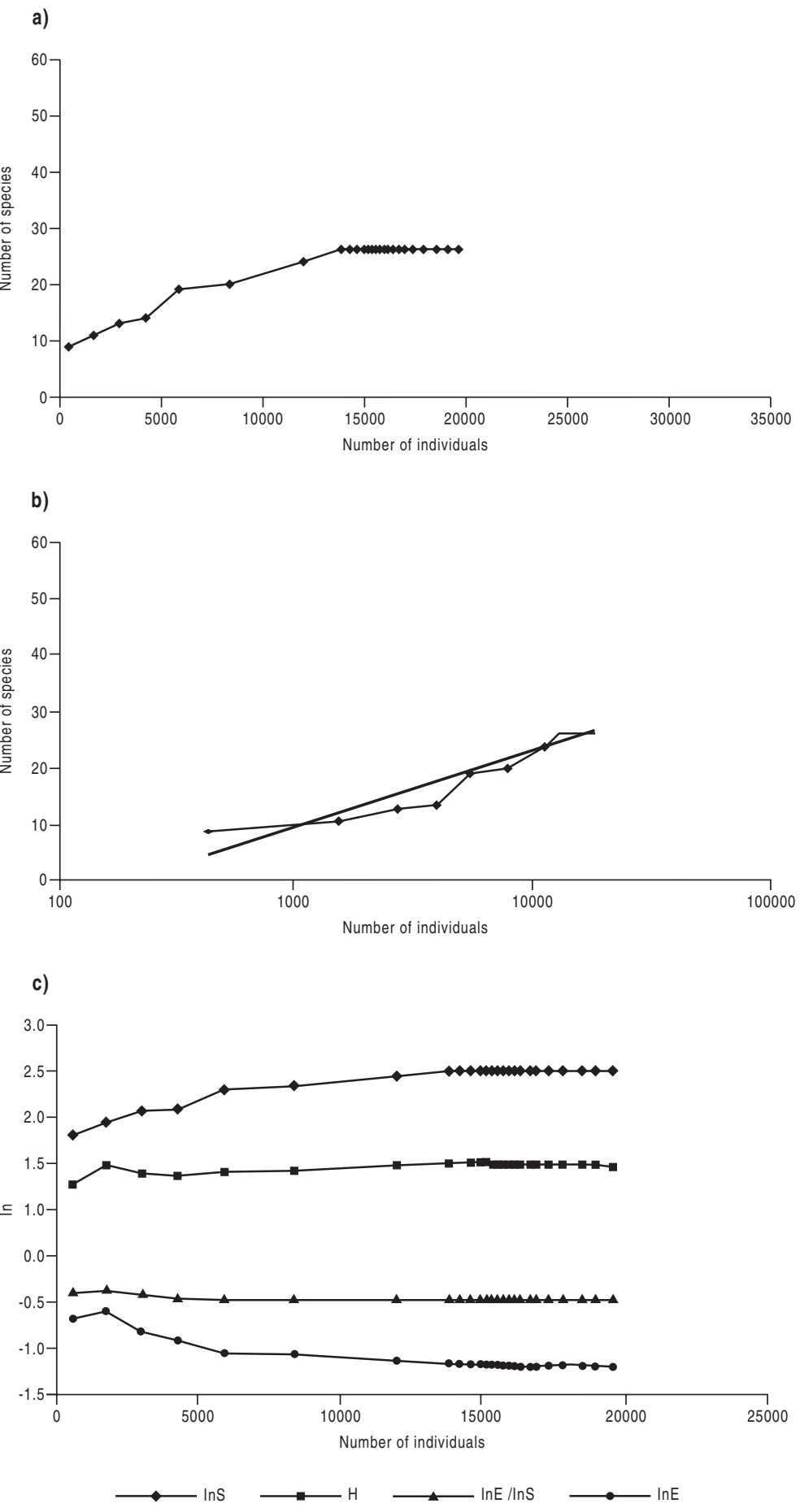

Fig. 6 (a) Cumulative increase in species and standing crop in living foraminifera over 12 months from the tidal flat (b) with logarithmic scale (the straight line is the log series trend line) and (c) SHE analysis. 

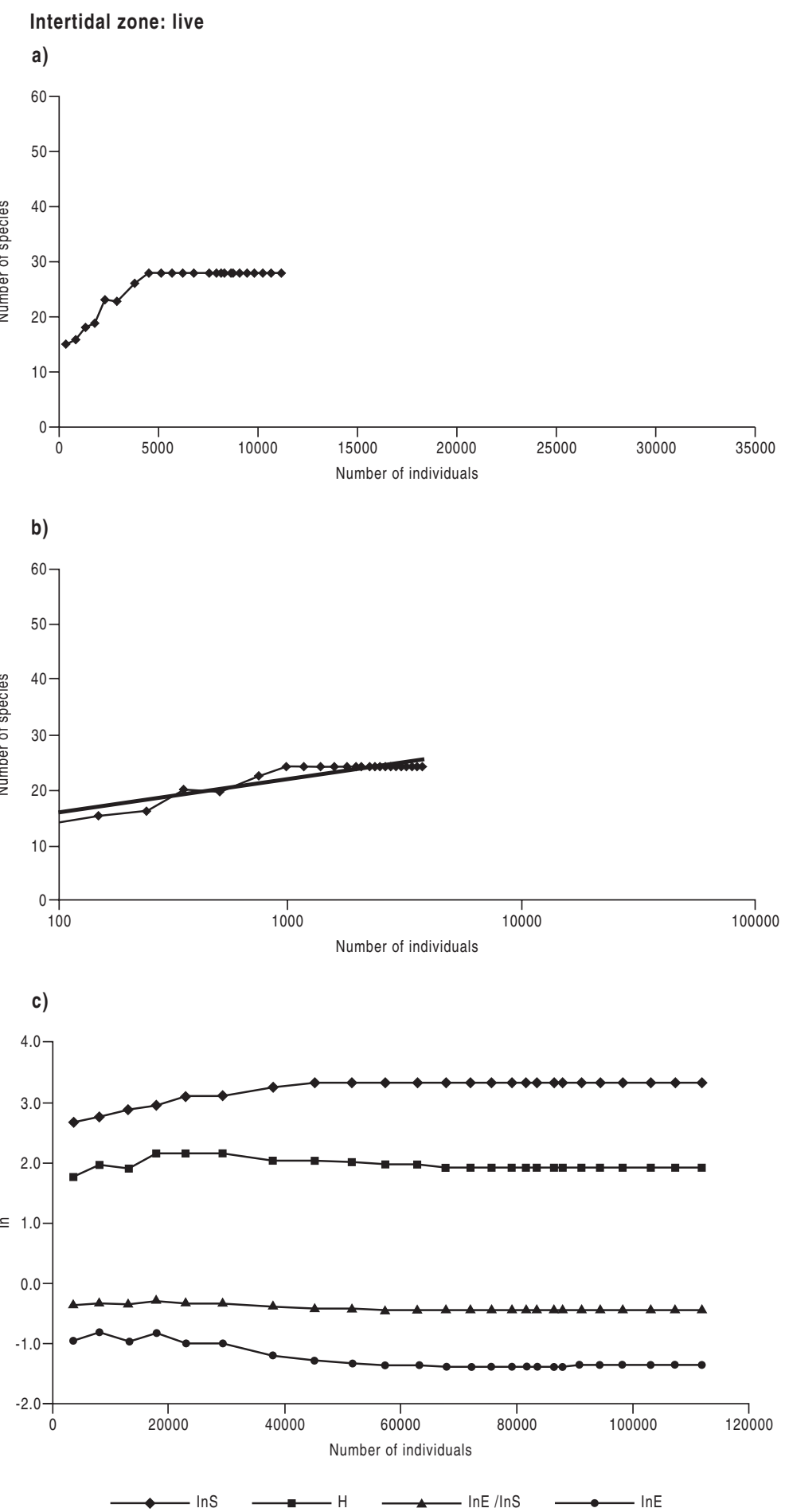

Fig. 7 (a) Cumulative increase in species and standing crop in living foraminifera over 12 months from the intertidal zone (b) with logarithmic scale (the straight line is the log series trend line) and (c) SHE analysis. 


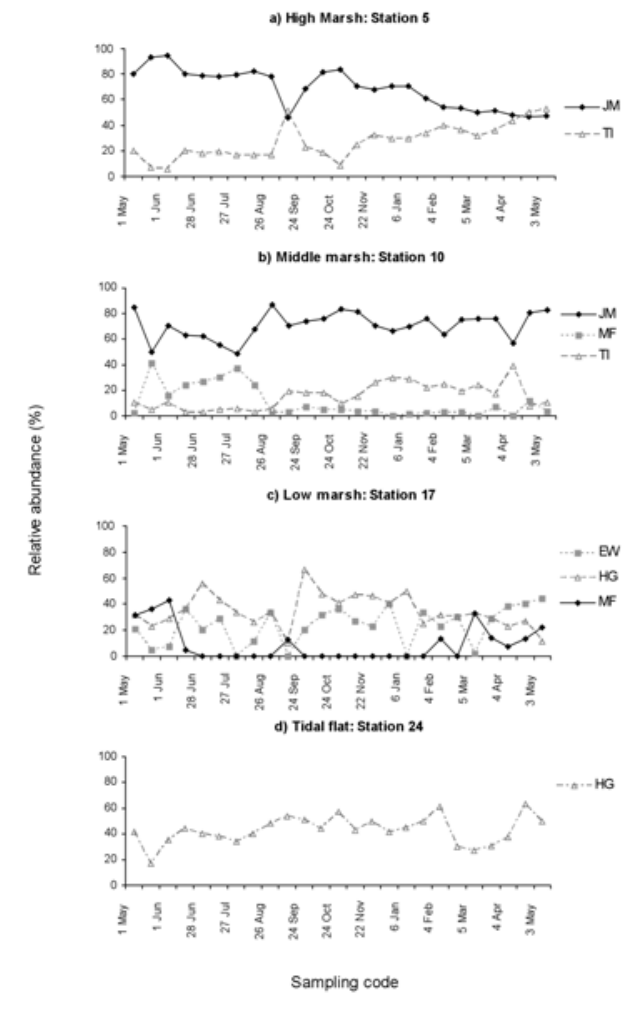

Fig. 8 Relative abundance of the dominant dead species during the twelve month study period from (a) high, (b) middle and (c) low marshes and (d) tidal flat environments. Species abbreviation: $\mathrm{EW}=$ Elphidium williamsoni; $\mathrm{HG}=$ Haynesina germanica; $\mathrm{JM}=$ Jadammina macrescens; $\mathrm{MF}=$ Miliammina fusca. 
High marsh: dead

a)
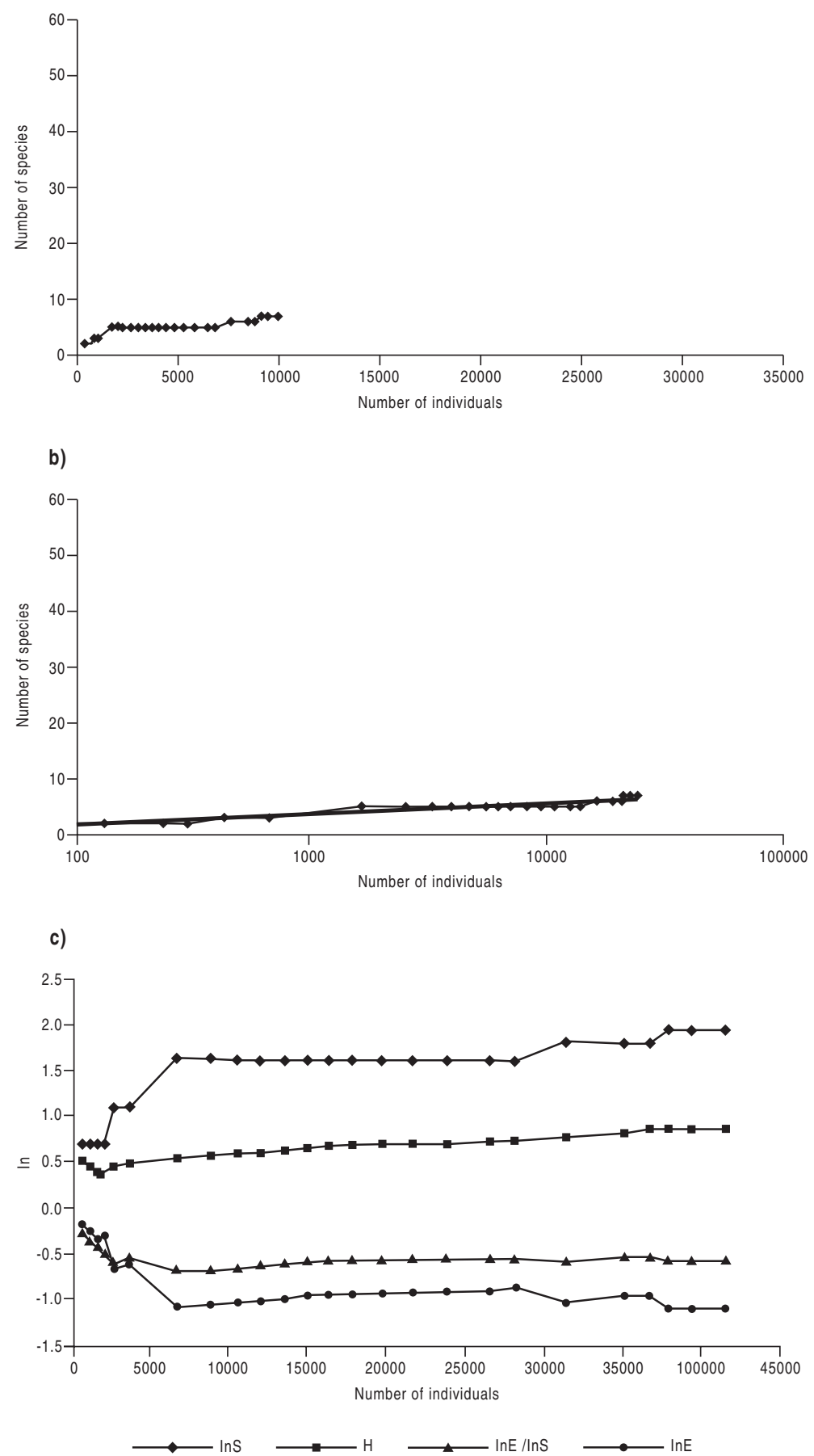

Fig. 9 (a) Cumulative increase in species and individuals in dead foraminifera over 12 months from the high marsh (b) with logarithmic scale (the straight line is the log series trend line) and (c) SHE analysis. 

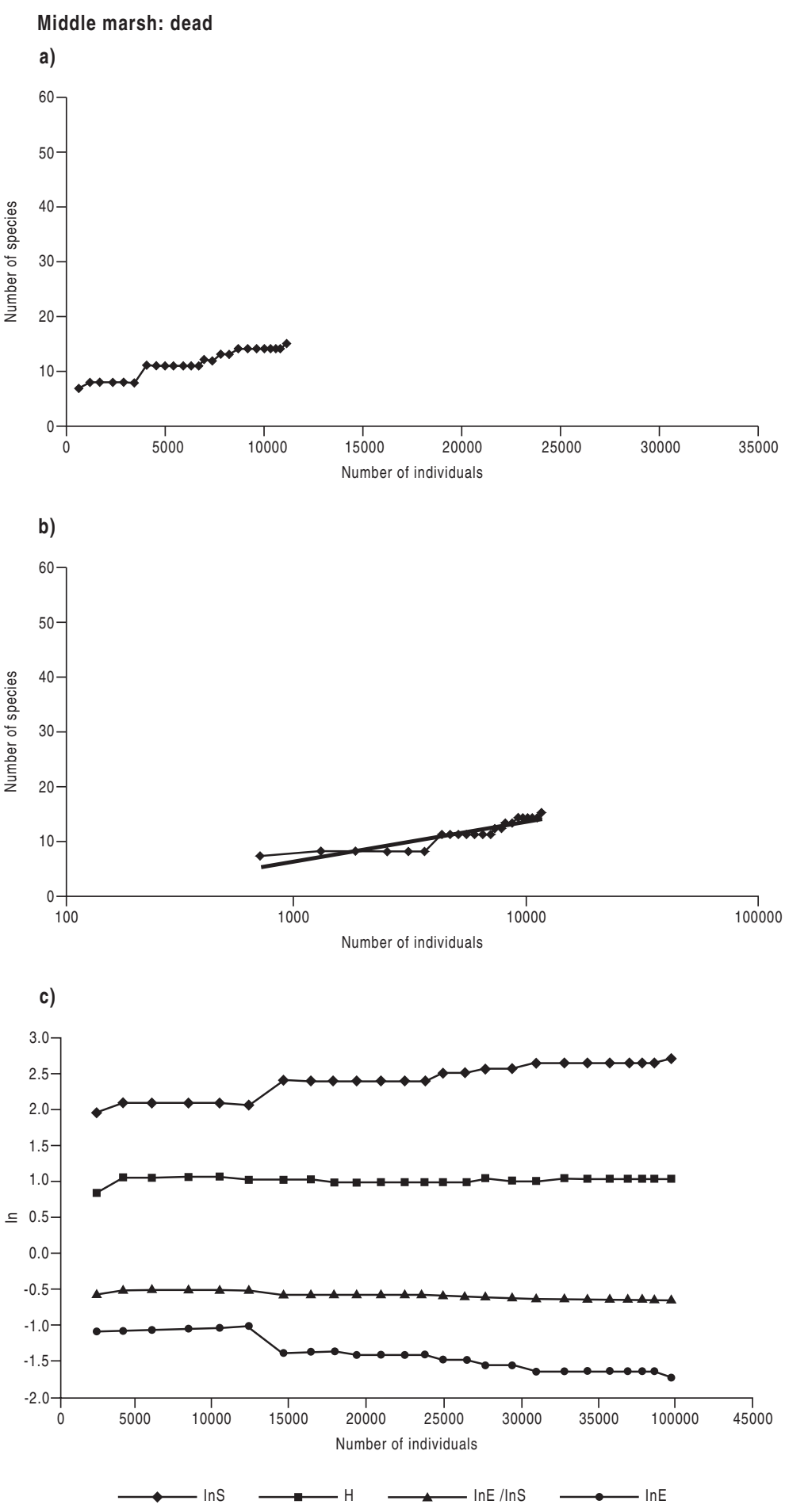

Fig. 10 (a) Cumulative increase in species and individuals in dead foraminifera over 12 months from the middle marsh (b) with logarithmic scale (the straight line is the log series trend line) and (c) SHE analysis. 
Low marsh: dead

a)
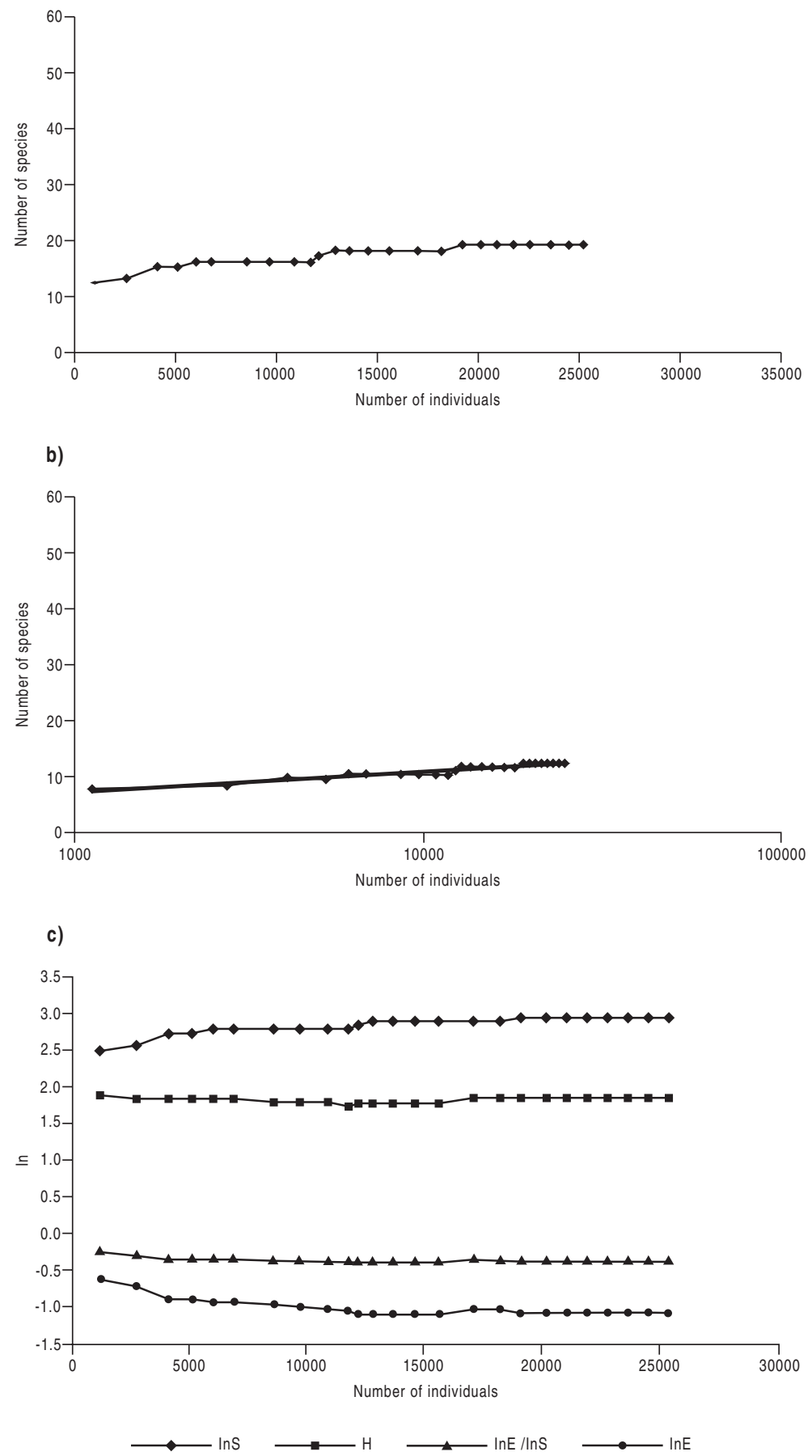

Fig. 11 (a) Cumulative increase in species and individuals in dead foraminifera over 12 months from the low marsh (b) with logarithmic scale (the straight line is the log series trend line) and (c) SHE analysis. 
Tidal flat: dead
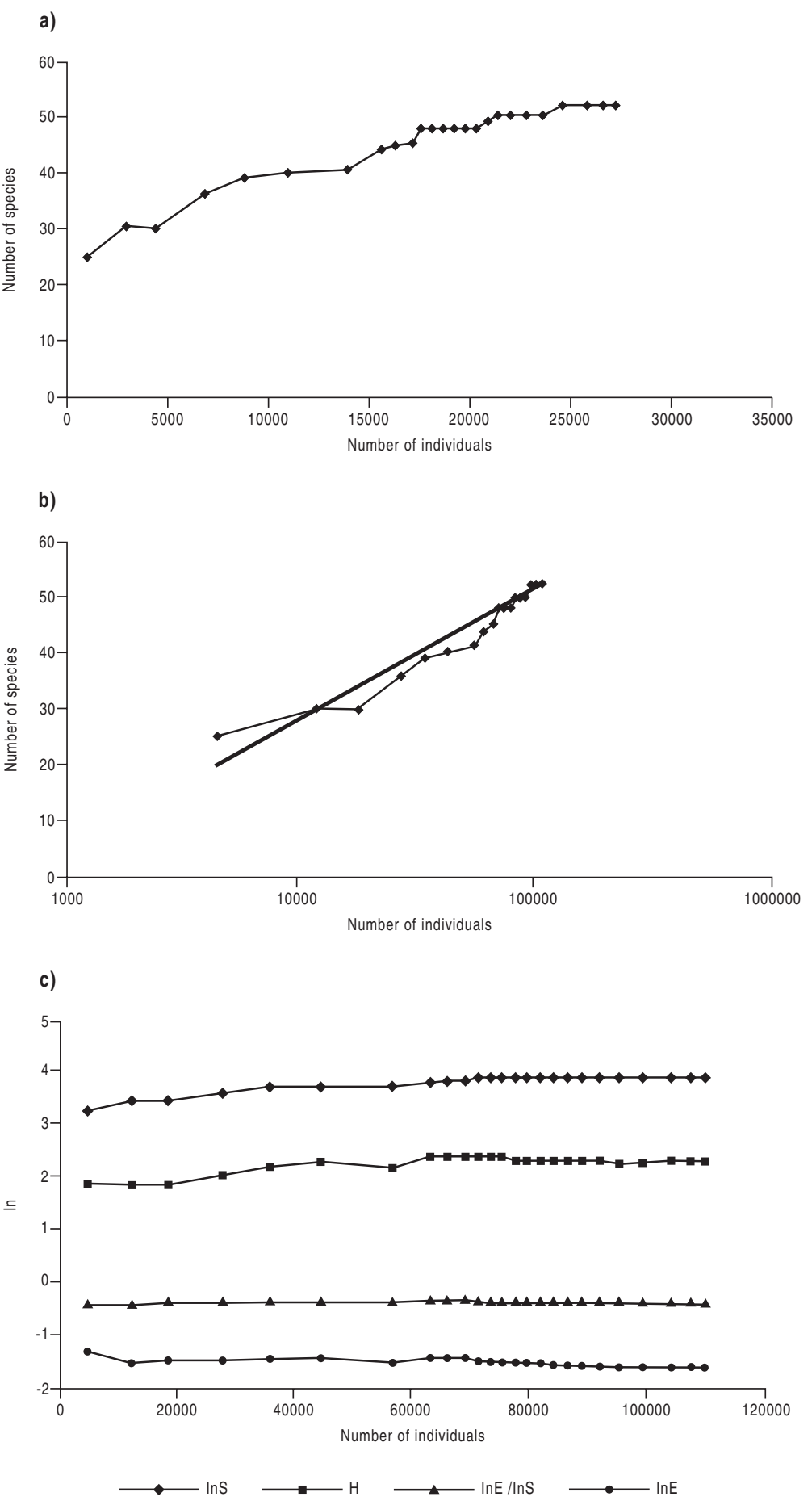

Fig. 12 (a) Cumulative increase in species and individuals in dead foraminifera over 12 months from the tidal flat (b) with logarithmic scale (the straight line is the log series trend line) and (c) SHE analysis. 

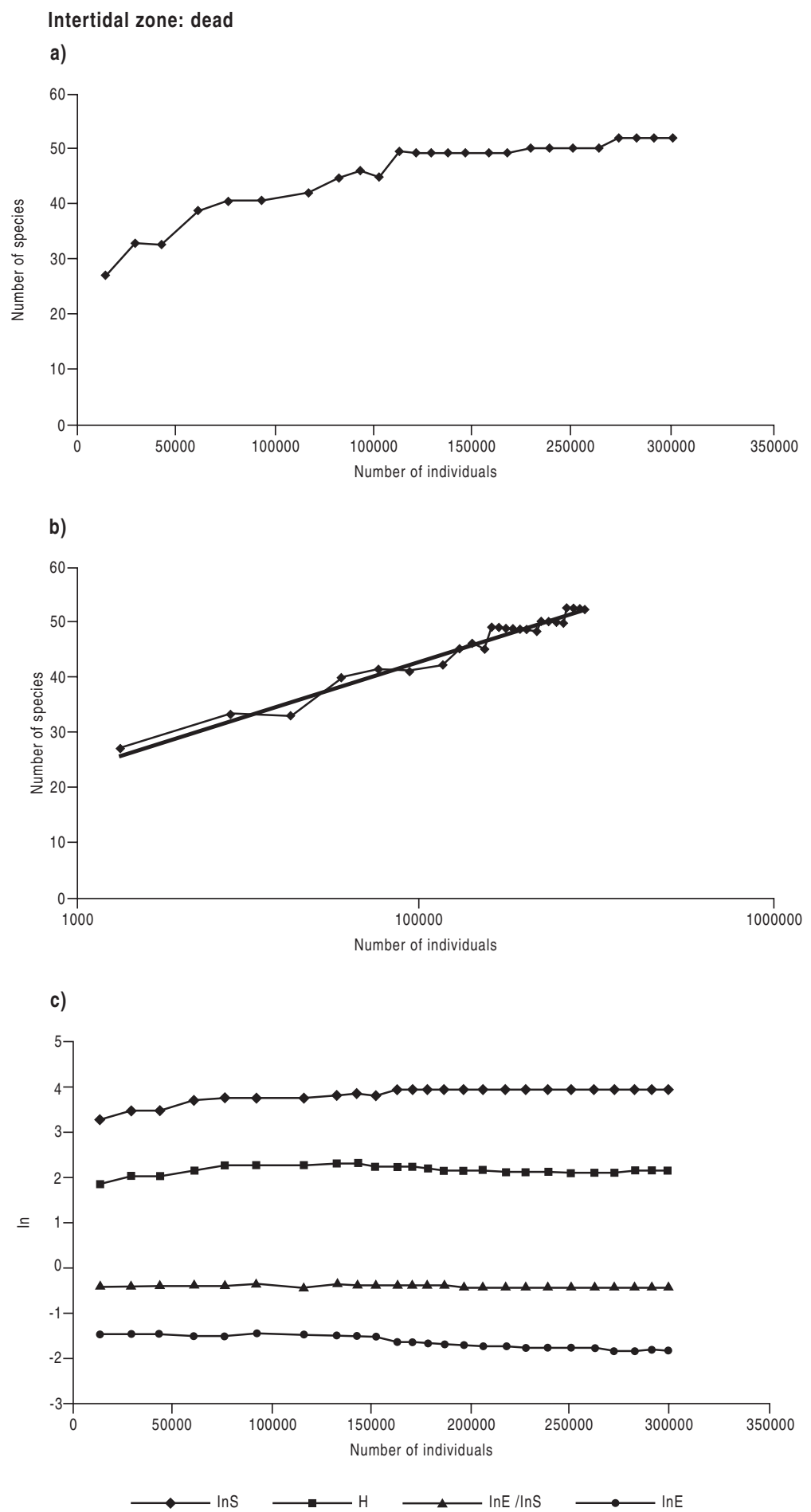

Fig. 13 (a) Cumulative increase in species and individuals in dead foraminifera over 12 months from the intertidal zone (b) with logarithmic scale (the straight line is the log series trend line) and (c) SHE analysis. 

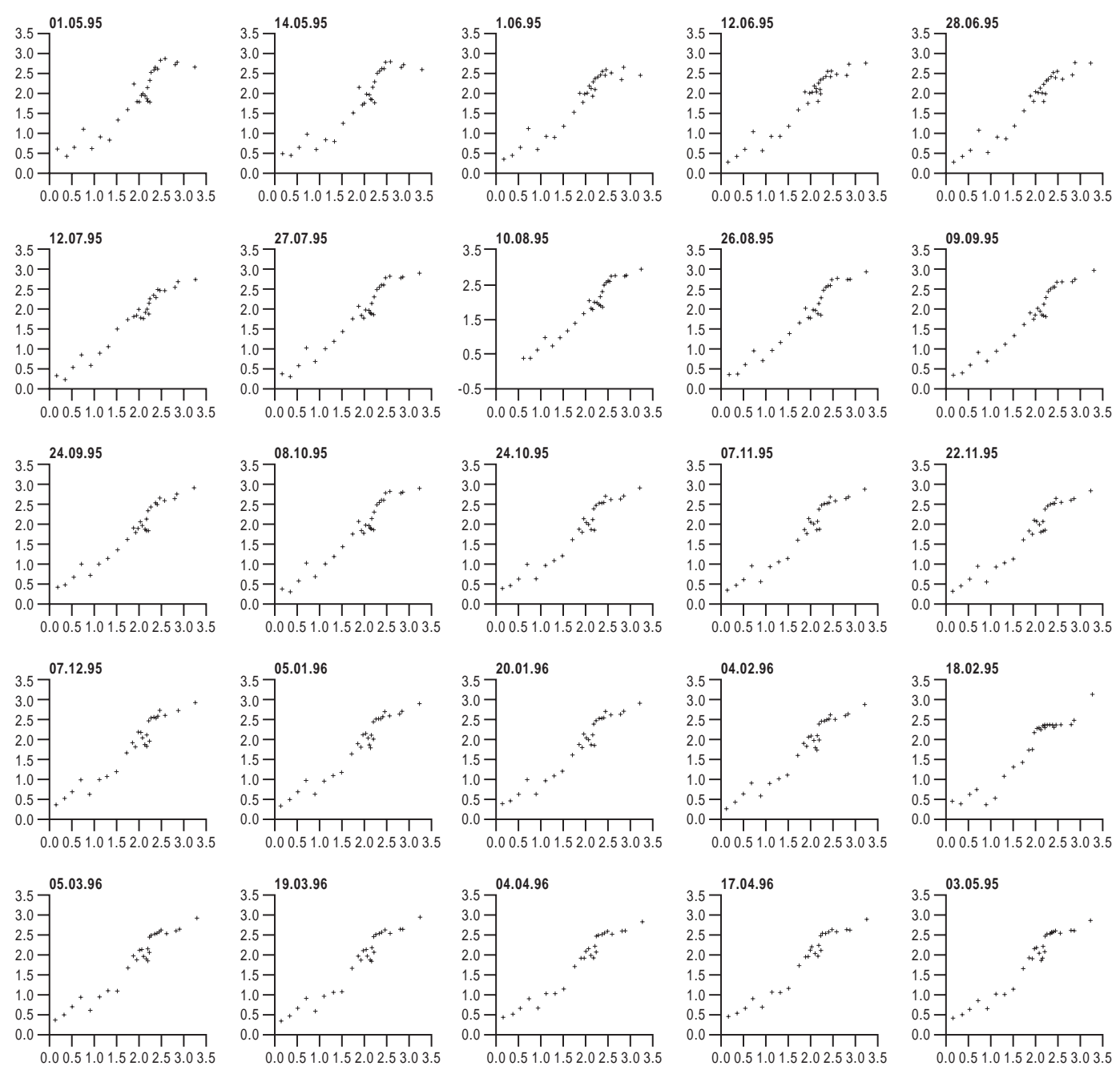

Fig. 14 Scatter graphs showing observed versus foraminiferal predicted elevations produced from two-weekly cumulative datasets. 


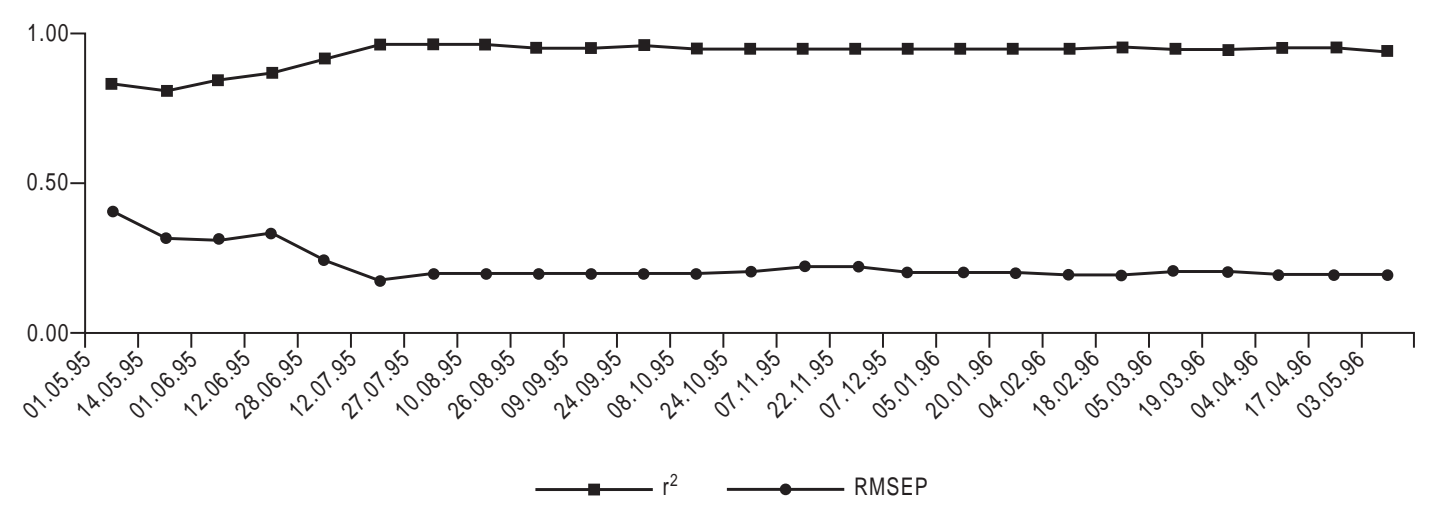

Fig. 15 Performance $\left(r^{2}\right.$ and root means squared error of prediction (RMSEP) of the foraminiferal-based transfer function produced from two-weekly cumulative datasets.

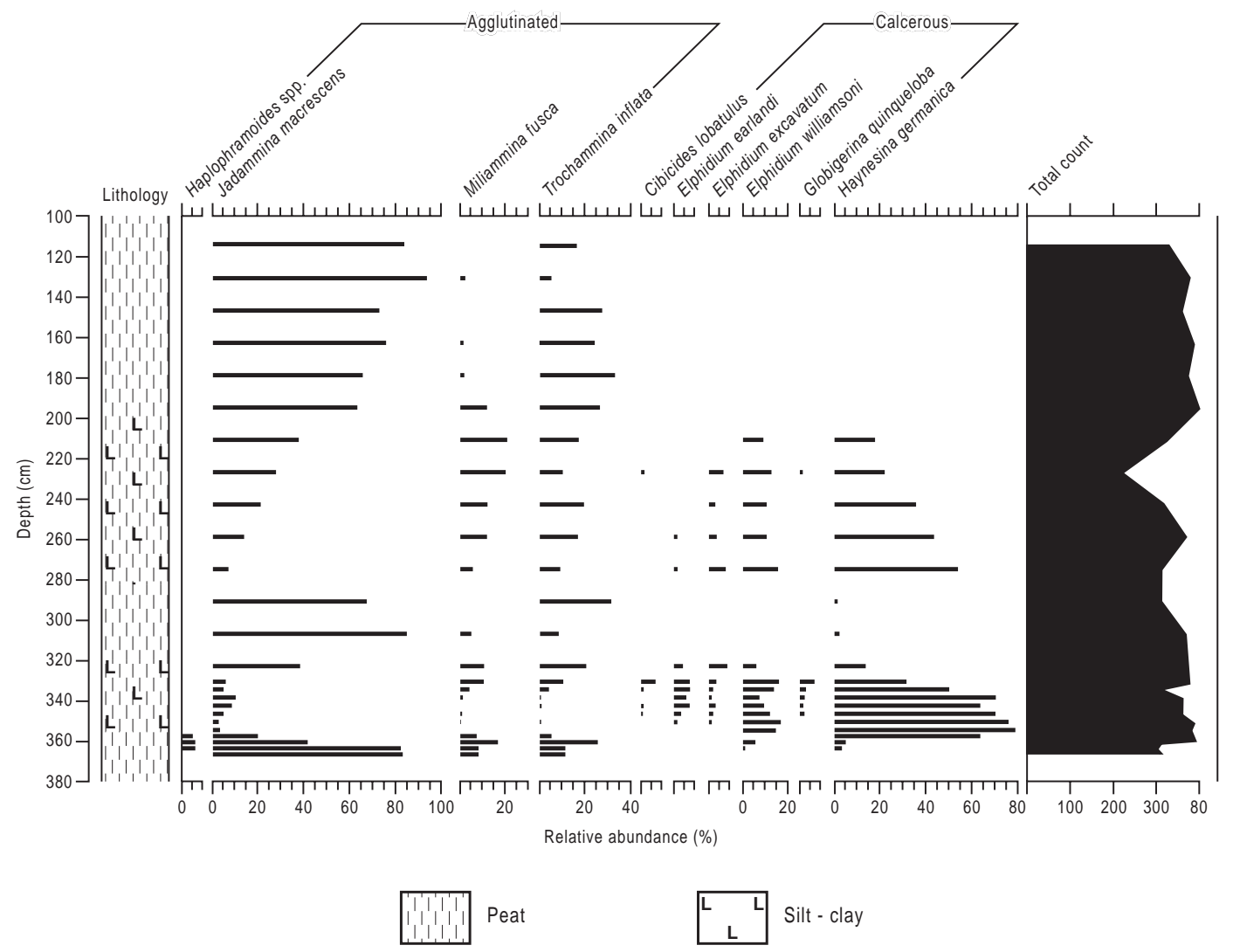

Fig. 16 Cowpen Marsh Core CM1 foraminiferal diagram. Foraminiferal abundance is calculated as a percentage of total foraminiferal tests (only species greater than $5 \%$ are shown). 
A

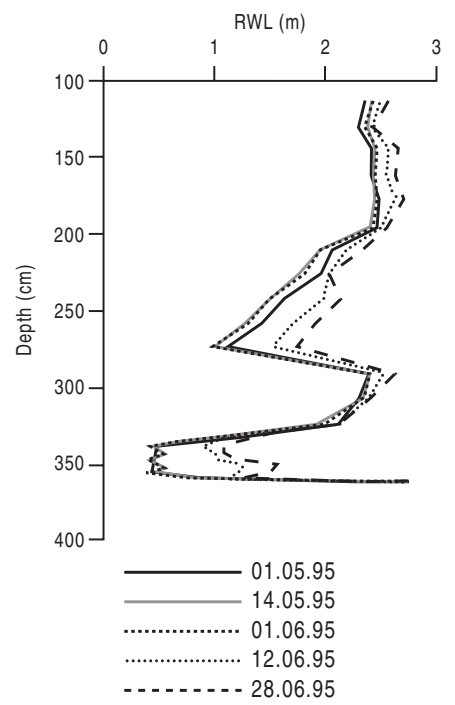

D

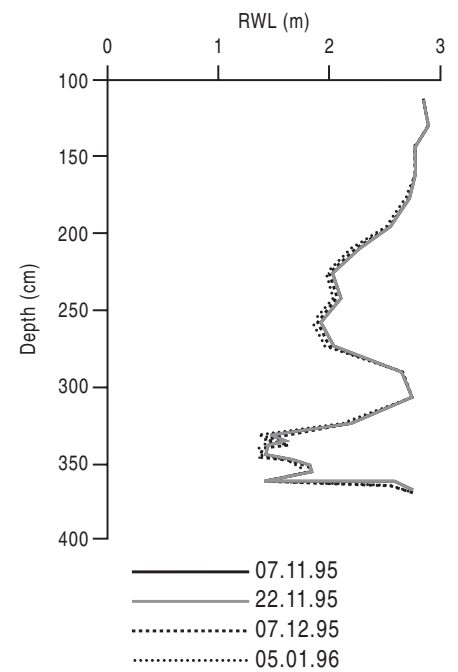

B

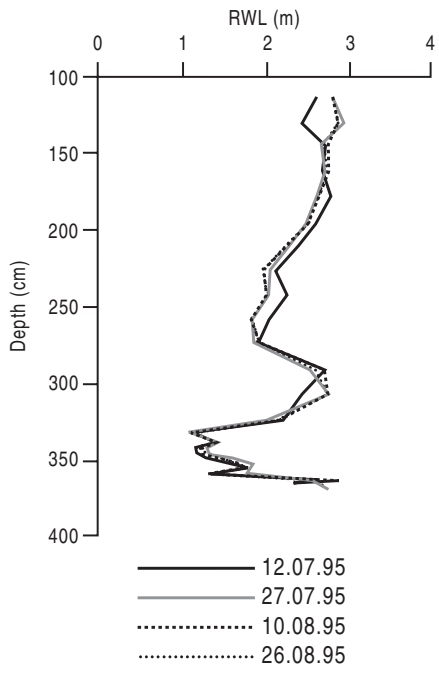

E

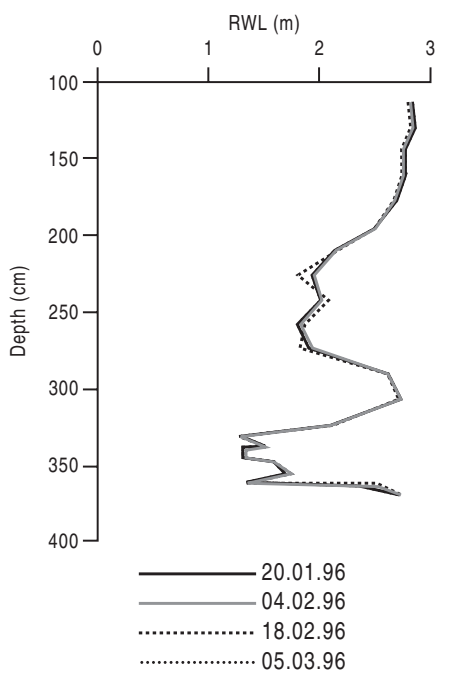

C

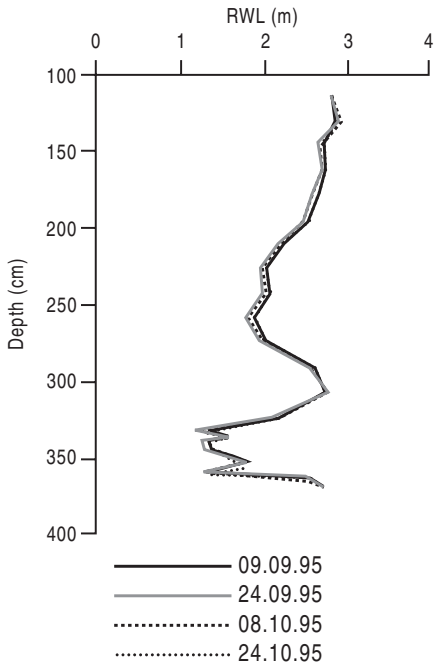

$\mathbf{F}$

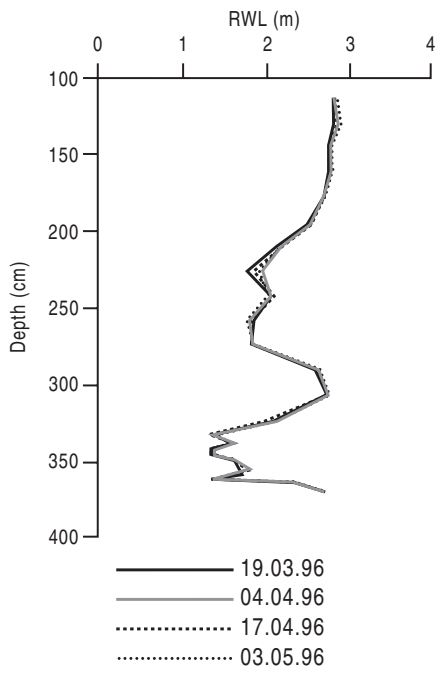

Fig. 17 Reference water level (RWL) reconstructions against depth below ground surface (cm) for Cowpen Marsh Core CM1 using foraminiferal-based transfer function produced from twoweekly cumulative datasets. (a) 01/05/1995 to 28/06/1995, (b) 12/07/1995 to 26/08/1995, (c) 09/09/1995 to 24/10/1995, (d) 07/11/1995 to 05/01/1996, (e) 20/01/1996 to 05/03/1996 and (f) 19/03/1996 to $03 / 05 / 1996$. 


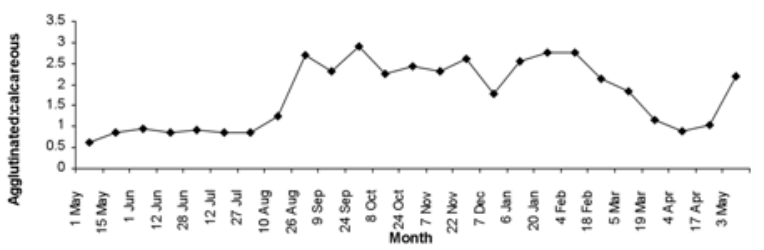

Fig. 18 Agglutinated versus calcareous ratio from each sampling intervals. 


\section{APPENDIX A}

\section{Foraminiferal taxonomy}

\begin{tabular}{ll}
\hline Species & Citation \\
\hline Arenoparrella mexicana & Trochammina inflata (Montagu) var. mexicana Kornfeld, 1931: p.86,
\end{tabular}

Cornuspira selseyensis

Elphidium earlandi (sensu

Murray, 1971)

Elphidium williamsoni

(Haynes, 1973)

Haynesina germanica

(Ehrenberg, 1840)

Jadammina macrescens

(Brady, 1870)

Miliammina fusca (Brady,

1870)

Nonionella opima

Pseudothurammina limnetes

Quinqueloculina oblonga

Tiphotrocha comprimata
Heron-Allen and Earland, 1909: p. 319, p. 15, figs 9-11.

not Elphidium earlandi Cushman, 1936: p. 85, pl. 15, fig. 5.

Elphidium earlandi Cushman; Murray, 1971: p.157, pl. 65, figs 1-7.

Elphidium williamsoni Haynes, 1973: p. 207, pl. 24, fig. 7, pl. 25, figs. 6, 9, pl. 27, figs. 1-3 [see synonymy].

Nonionina germanica Ehrenberg, 1840: p. 23 [figured in Ehrenberg, 1840b, pl. 2, figs. 1a-g].

Protelphidium anglicum Murray, 1965: p.149-150, pl. 25, figs. 1-5, pl. 26, figs 1-6

Trochammina inflata (Montagu) var. macrescens Brady, 1870: p. 290, pl. 11, figs. 5a-c.

Jadammina polystoma Bartenstein \& Brand, 1938: p.381, text-figs. 1-3.

Jadammnina macrescens (Brady); Brönnimann \& Whittaker, 1984a: p. 303309, figs. 1-21 (lectotype erected).

Quinqueloculina fusca Brady, 1870: p. 286, pl. 11, figs. 2a-c.

Miliammina fusca Brady; Murray, 1971: p. 21, pl. 3, figs. 1-6.

Cushman, 1947: p. 90, pl. 20, figs 1-3.

Thurammina? limnetes Scott \& Medioli, 1980: p. 43, 44, pl. 1, figs 1-3. Vermiculum oblongum Montagu, 1803: p. 522, pl. 14, fig. 9.

Trochammina comprimata Cushman \& Brönnimann, 1948: p. 41, pl. 8, figs 
(Cushman \& Brönnimann,

1948)

Trochammina inflata

(Montagu, 1808)
$1-3$.

Nautilus inflatus Montagu, 1808: p. 81, pl. 18, fig. 3.

Trochammina inflata (Montagu); Brönnimann \& Whittaker, 1984b: p. 311315, figs 1-11 (neotype erected). 